\begin{tabular}{ll}
\hline \hline MINING AND METALLURGY INSTITUTE BOR & ISSN: 2334-8836 \\
& UDK: 622 \\
\hline \hline
\end{tabular}

Novica Staletović, Srđa Kovačevic ${ }^{* *}$, Miša Kovačevic ${ }^{* * *}$

\title{
DEVELOPMENT THE MODEL OF ASSESSMENT THE OH\&S RISKS FOR THE WORK PLACE DRILLER IN THE PROCESS OF GEOLOGICAL EXPLORATORY DRILLING
}

\begin{abstract}
This work gives a model of OH\&S risk assessment for the workplace driller in the process of implementation the geological exploratory works. Model of OH\&S risk assessment for the workplace driller is based on ISO 31010 Standard and fulfilling the requirements of OHSAS 18001 and legal regulations. In this case, a partially adjusted and optimized Kinny method was used. Model of OH\&S risk assessment provides a reasonable basis for development and implementation the system of occupational health and safety management in accordance with BS OHSAS 18001: 2008, since it is practically applied and tested in the organizations dealing with geological exploratory drilling, such as "Geops Balkan Drilling Services" Ltd., Drillex International Ltd., International Drilling Service Ltd. and Stara Planina Resources Ltd.
\end{abstract}

Keywords: OH\&S risk, driller, geology, exploratory drilling

\section{INTRODUCTION}

Safety and health at work is a very important part of work at every employer regardless the type of activity of the employer. By the systematic approach to the safety and health at work, the importance of prevention in all phases of work is given. Assessment of OH\&S risk tends to control the risk in order to eliminate the dangers and hazards of injury, occupational diseases and illnesses related to work and to establish the system of occupational health and safety at work (OHSAS). Achieving the quality in management the system of health and safety at work is impossible without complying with the basic legal requirements of assessment the $\mathrm{OH} \& \mathrm{~S}$ risks.

Organization whose activity is geological exploratory drilling is expected to be confronted with significant $\mathrm{OH} \& \mathrm{~S}$ risks. If
$\mathrm{OH} \& \mathrm{~S}$ risks are not adequately assessed and placed under the control, they may affect in a negative way the achievement of organization objectives. The goals of organization can refer to a range of activities, from strategic initiatives through to operations and can be reflected in the non-compliances with the regulations and other requirements. Considering that the technological process of exploratory drilling, consisted of operations involving a significant number of hazardous materials to the potential $\mathrm{OH} \& \mathrm{~S}$ risks, may be even greater.

Management of $\mathrm{OH} \& \mathrm{~S}$ risk involves the application of logical and systematic methods for identifying, analyzing and assessment the $\mathrm{OH} \& \mathrm{~S}$ risks during the process of exploratory drillings, monitoring and review of risks to the aim of effective and efficient

\footnotetext{
* Faculty of Ecology and Environmental Protection, Belgrade, e-mail: nomstale@open.telekom.rs ** JPPK “Kosovo” Obilić, e-mail: srdja.kovacevic@sbb.rs

*** YUQS, Trg Nikole Pašića 3/I, Belgrade; e-mail: kovacevicmisa90@gmail.com
} 
management of integrated quality management systems (ISO 9001), environmental protection (ISO 14001) and occupational health and safety at work (OHSAS 18001).

The aim of this research is to evaluate the OH\&S risks in the process of geological exploratory drilling with finding the answers to the following basic questions:

- What can happen in the process of exploratory drilling and why (hazard identification)?

- What are the probabilities of danger and hazards?

- Can it be managed by the assessed OH\&S risks and whether it requires further treatment of reduction the $\mathrm{OH} \& \mathrm{~S}$ risks?

- How to make the planning of measures to protect the health and safety at work that may affect the probability reduction of danger and hazard occurrence?

In accordance with determined aim of research, the following research hypothesis is set:

a) Based on a systemic approach it is possible to make a positive identification, risk analysis and assessment of $\mathrm{OH} \& \mathrm{~S}$ risks and to establish the mechanisms to control the assessed $\mathrm{OH} \& \mathrm{~S}$ risks.

Based on the identification of problems, set objective and hypotheses of research, the following research tasks have resulted, namely:

1) to perform a system analysis, and define the model and methods of assessment the $\mathrm{OH} \& \mathrm{~S}$ risks;

2) to identify the hazards, determine the probability of occurrence and potential consequences;

3) to assess the $\mathrm{OH} \& \mathrm{~S}$ risks for a specific job position;

4) to define a Plan of measures to control the increased OH\&S risks.

In order to fulfill the tasks of research and achieving the objective of testing the proposed hypotheses of research, the known methods are used are that have contributed to improving the methodology of research, namely:
1) descriptive method (method of observation and description) through the analysis of available data;

2) method of analysis the theory and practice;

3) method of general system theory or systematic approaches and system analysis;

4) method of the process modeling, and development the flow charts.

\section{THEORETICAL APPROACH, SELECTED METHODOLOGICAL APPROACH AND METHODS OF ASSESSMENT THE OH\&S RISKS}

\subsection{Theoretical approach to assessment the $\mathrm{OH} \& \mathrm{~S}$ risks}

To meet the requirements of the Standard OHSAS 18001 as well as the requirements of legislation, it is necessary for all hazards and dangers that occur and/or may be occured at the workplace driller in the process of exploratory drillings to carry out the assessment of $\mathrm{OH} \& \mathrm{~S}$ risks. For the purpose of effective and efficient assessment of OH\&S risks, it is necessary to use the appropriate method that will provide the proactive, but not reactive assessment results [10]. The effectiveness and efficiency of the OH\&S system can not be only achieved by $\mathrm{y}$ assessment the $\mathrm{OH} \& \mathrm{~S}$ risks, but it is necessary that after the assessment of $\mathrm{OH} \& \mathrm{~S}$ risks of organizations, to provide conditions that the results of the assessment $\mathrm{OH} \& \mathrm{~S}$ risks are taken into account in establishing the OH\&S management system and to define the management plan with increased $\mathrm{OH} \& \mathrm{~S}$ risks.

In the world and in the Republic of Serbia, the most widely used tool for establishment, maintenance and upgrading the occupational health and safety at work system is the Standard OHSAS 18001. OH\&S system is a structured process for overcoming the $\mathrm{OH} \& \mathrm{~S}$ risks. The afforementioned standard has precisely provided the requirements of some key elements of occupational health 
and safety at work, such as: identifying the hazards and dangers that may arise where the compulsory taking into account the behavior and abilities of employees, management, communication, cooperation and consulting with employees.

To manage with $\mathrm{OH} \& \mathrm{~S}$ risks means finding one acceptable combination that allows actions to improve safety and health at work and elimination of all dangers and hazards that lead into question the optimal functioning of OH\&S system. Management of $\mathrm{OH} \& \mathrm{~S}$ risks can be achieved with assumptions that include the following:

- timely identification of all dangers and hazards;

- making a list of dangers and hazards that affect the OH\&S system;

- analysis of previous data on consequences of injuries at work, occupational diseases and diseases related to work;

- analysis of individual dangers and hazards and their grouping by similarity;

- analysis of interdependence the individual dangers and hazards and their potential consequences;
- assessment of OH\&S risks for the established list of dangers and hazards;

- establishment an environment that fosters a tradition of teamwork;

- development of methods and techniques for assessment and management the OH\&S risks;

- establishment an optimal level of safety at work;

- adoption of goals, plans and programs for management of assessed OH\&S risks.

For effective control OH\&S risks risks, it is necessary to know to manage the information, based on which the conclusions and decisions are made, i.e. it is necessary to pay attention to the quality of information which is contained in the Act on assessment the $\mathrm{OH} \& \mathrm{~S}$ risks.

Assessment of $\mathrm{OH} \& \mathrm{~S}$ risks risks in the business process is in no case a constant, but a dynamic value that changes from moment to moment. Every time some elements of dangers and hazards is changed, the level of $\mathrm{OH} \& \mathrm{~S}$ risks is also changed. There is a standard that defines the process of risk assessment ISO 31010: 2010 [8].

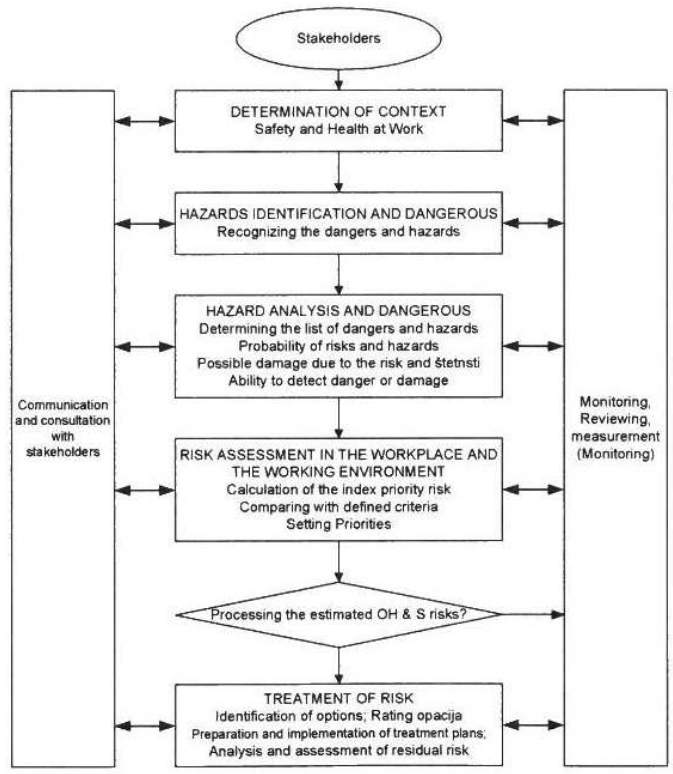

Figure 1 Block diagram of assessment process the OH\&S risks [8], [12] 


\subsection{Selected method of assessment the OH\&S risks}

The Kinny method is one of the methods by which it is possible to assess the $\mathrm{OH} \& \mathrm{~S}$ risks. OH\&S risks change over time in three basic categories, which are analyzed by the Kinny method, as follows:

- probability of dangers and hazards;

- severity of consequences that may result from the occurrence of dangers and hazards;

- frequency of incidence the dangers and hazards.

Based on identification of danger at the workplace and working environment and statistical data processing about dangerous events (occupational injuries), hazardous materials and critical points of the process, the assessment of OH\&S can be done.

The process of hazard and danger identification and evaluation the impact can achieve the following:

- to identify all dangers and hazards that may impact the workplace and working environment;

- to analyze the impacts of hazards and dangers at the workplace and working environment;

- to establishe an evaluation system of any dangers and hazards;

- to determine the significance of any dangers and hazards.

Parameters of analysis are numerically evaluated, and the final assessment of $\mathrm{OH} \& \mathrm{~S}$ risks at the workplace and work en vironment is expressed numerically. The default setting of the Kinny method in assessment the risks at the workplace and work environment is essentially simple and easy to understand. The essence of the method consists in realization the following activities:

a) determining the all potential dangers and hazards that are/or may incur as the result of work process;

b) determining the possible causes of each danger and hazard;

c) analysis of each danger and hazard in order to determine using the analytical methods:

- probability of occurrence the potential danger and hazard;

- serious consequences which employee suffers in occurrence of danger and hazard ;

- frequency of danger and hazard occurrence.

d) evaluating the level of risk is is made by the product of three factors:

- probability of dangers and hazards - V;

- serious consequencies due to occurrence of dangers and hazards - $\mathrm{P}$;

- frequency of occurrence the dangers and hazards - $U$;

Evaluation of the risk $\mathbf{R}$ is done according to the formula:

$\mathbf{R}=\mathbf{V} \times \mathbf{P}$

Table 1 Matrix of risk assessment by Kinny method [11]

\begin{tabular}{|c|c|c|c|}
\hline \multirow{2}{*}{ Identified danger or hazard } & \multicolumn{2}{|c|}{ ASSESSMENT OF OH\&S RISKS } & \multirow{2}{*}{$\begin{array}{l}R=V \times P \\
\text { Risk level } R\end{array}$} \\
\hline & Probability $v$ & Consequence $\mathbf{P}$ & \\
\hline $\mathrm{x}$ & & & \\
\hline $\mathrm{y}$ & & & \\
\hline $\mathrm{Z}$ & & & \\
\hline
\end{tabular}




\subsubsection{Criteria for probability assessment - $V$}

Table 2 Description of criteria for probability assessment of occurrence the dangers and hazards [11]

\begin{tabular}{|c|l|}
\hline RANK & DESCRIPTION OF CRITERIA FOR PROBABILITY ASSESSMENT - V \\
\hline $\mathbf{0 . 1}$ & Hardly conceivable \\
\hline $\mathbf{0 . 2}$ & Practically unbelievable \\
\hline $\mathbf{0 . 5}$ & There is, but only very unlikely \\
\hline $\mathbf{1}$ & Unlikely, but possible in limited cases \\
\hline $\mathbf{3}$ & Little as possible \\
\hline $\mathbf{6}$ & It is quite possible \\
\hline $\mathbf{1 0}$ & Predictably, the expected \\
\hline
\end{tabular}

\subsubsection{Criteria for assessment of} consequencies - $P$

Table 3 Description of criteria for assessment of consequencies in occurrence of dangers and hazards [11]

\begin{tabular}{|c|l|}
\hline RANK & \multicolumn{1}{c|}{$\begin{array}{c}\text { DESCRIPTION OF CRITERIA FOR ASSESSMENT OF } \\
\text { CONSEQUENCIES - P }\end{array}$} \\
\hline $\mathbf{1}$ & Illness, injury which requires first aid and any other treatment \\
\hline $\mathbf{2}$ & Medical treatment by a physician \\
\hline $\mathbf{3}$ & Severe-disability, serious individual injury with hospitalization and lost days \\
\hline $\mathbf{6}$ & Very serious individual-fatal accidents \\
\hline $\mathbf{1 0}$ & Catastrophic-with multiple fatalities \\
\hline
\end{tabular}

\subsubsection{Criteria for assessment the} frequency of occurrence the dangers and hazards - $U$

Table 4 Description of criteria for assessment the frequency of occurrence the dangers and hazards [11]

\begin{tabular}{|c|l|}
\hline RANK & \multicolumn{1}{|c|}{ DESCRIPTION OF CRITERIA FOR FREQUENCY - U } \\
\hline $\mathbf{1}$ & Exposed rarely (annually) \\
\hline $\mathbf{2}$ & Exposed monthly \\
\hline $\mathbf{3}$ & Exposed weekly \\
\hline $\mathbf{6}$ & Exposed daily \\
\hline $\mathbf{1 0}$ & Exposed permanent, continuous \\
\hline
\end{tabular}




\subsubsection{Criteria for classification}

the risk level $(R)$

Table 5 Criteria for determining the risk level [11]

\begin{tabular}{|c|c|c|c|}
\hline Total score & $\begin{array}{l}\text { Risk } \\
\text { class }\end{array}$ & $\begin{array}{c}\text { Classification } \\
\text { of risk level }\end{array}$ & Description the classification of risk level \\
\hline$>0.1<20$ & $\mathbf{R} \mathbf{I}$ & $\begin{array}{c}\text { Negligible } \\
\text { risk }\end{array}$ & No action is required. \\
\hline$>\mathbf{2 0}<\mathbf{7 0}$ & R II & Low risk & $\begin{array}{l}\text { There is no need for additional r activities in the man- } \\
\text { agement of operation. } \\
\text { An economically cost-effective solution or improve- } \\
\text { ment without additional investmen could be consid- } \\
\text { ered. It is necessary to monitor the situation in order } \\
\text { to possess information on implementation the pre- } \\
\text { scribed activities. }\end{array}$ \\
\hline$>\mathbf{7 0}<\mathbf{2 0 0}$ & R III & Medium risk & $\begin{array}{l}\text { Efforts are needed to reduce the risk, but the costs of } \\
\text { prevention have to be carefully planned and limited to } \\
\text { a certain level. } \\
\text { It is necessary to define a deadline for implementation } \\
\text { of improvements. } \\
\text { For those events where extremely dangerous conse- } \\
\text { quence can be occurred, it is necessary to further verify } \\
\text { the probability of occurrence of such events in order to } \\
\text { define the required level of activity to mitigate risk. }\end{array}$ \\
\hline$>200<400$ & R IV & High risk & $\begin{array}{l}\text { One must not start with a given activity, while the level } \\
\text { of risk is not reduced. } \\
\text { Significant resources are needed to reduce the risk. } \\
\text { If the risk is applied to all started activities, it is neces- } \\
\text { sary to take urgent actions to reduce the level of risk. }\end{array}$ \\
\hline$>400<1000$ & $\mathbf{R} \mathbf{V}$ & $\begin{array}{c}\text { Extremely } \\
\text { high risk }\end{array}$ & $\begin{array}{l}\text { Activity must not be commenced nor continued until } \\
\text { the level of risk is reduced to an acceptable level. If } \\
\text { investing the limited resources it is not possible to } \\
\text { reduce the level of risk to an acceptable level, the } \\
\text { activity must remain prohibited. }\end{array}$ \\
\hline
\end{tabular}

\subsubsection{Categorization and characterization of risk}

Table 6 Criteria for categorization and characterization of risks [11]

\begin{tabular}{|c|c|c|}
\hline Assessment the risk level & Categorization of risk level & Risk characterization \\
\hline R I & Negligible risk & Acceptable risk \\
\hline R II & Low risk & Acceptable risk \\
\hline R III & Medium risk & Increased risk \\
\hline R IV & High risk & Unacceptable risk \\
\hline R V & Extremely high risk & Unacceptable risk \\
\hline
\end{tabular}


Table 7 Description of risk characterization [11]

\begin{tabular}{|c|c|}
\hline Risk characterization & Description of risk characterization \\
\hline Acceptable risk & Risk for which there is assessment and presumption that it will not \\
\hline Acceptable risk & $\begin{array}{l}\text { result in: } \\
\text { - occupational injuries and illnesses related to work, } \\
\text { - inconsistency with legislation and / or deviation from the prescribed } \\
\text { work organization, and } \\
\text { - deviation from the prescribed policy of the health protection and } \\
\text { safety at work system in organization. }\end{array}$ \\
\hline Increased risk & $\begin{array}{l}\text { Risk for which there is assessment and presumption that it will } \\
\text { cause in the certain circumstances: } \\
\text { - occupational injuries and illnesses related to work, } \\
\text { - partly inconsistency with legislation and / or deviation from the } \\
\text { prescribed work organization, and } \\
\text { - occasional deviation from the prescribed policy and objectives } \\
\text { of the system of health protection and safety at work. }\end{array}$ \\
\hline Unacceptable risk & $\begin{array}{l}\text { Risk for which there is assessment and presumption that it directly } \\
\text { cause: } \\
\text { - occupational injuries and illnesses related to work, inconsisten- } \\
\text { cy with legislation; } \\
\text { - deviation from the prescribed work organization, and } \\
\text { - deviation from the prescribed policys and objectives of the sys- } \\
\text { tem of health protection and safety at work. }\end{array}$ \\
\hline
\end{tabular}

3 RESEARCH RESULTS -

PRACTICAL EXAMPLE OF

ASSESSMENT THE OH\&S RISK

\begin{tabular}{|l|l|}
\hline $\begin{array}{c}\text { Job } \\
\text { position code }\end{array}$ & $\begin{array}{l}\text { IDENTIFYING AND DETERMINING THE DANGERS AND HAZARDS } \\
\text { AND RISK ASSESSMENT AT THE JOB POSITION: DRILLER - GEO- }\end{array}$ \\
\cline { 1 - 2 } III GROUP & LOGICAL EXPLORATORY DRILLING \\
\hline 1 GENERAL DATA ON JOB POSITION \\
\hline 1.1 Name of work organization: & "GEOPS BALKAN DRILING SERVICES" LTD. \\
\hline 1.2 Sector: & Conduction the geological exploratory drilling \\
\hline 1.3 Service: & $/$ \\
\hline 1.4 Department: & $/$ \\
\hline
\end{tabular}

\section{DATA ON THE WORK PROCESS:}

2.1 Jobs by job classification and work tasks (description):

Driller - Geological exploratory drilling:

Works are done using the appropriate machines and methods for exploration of mineral resources. Drilling is carried out in geological surveyed areas in order to find the solid mineral resources. Geotechnical drilling machine is mounted ana special vehicle with caterpillars on which all working and driving parts of the machine are also installed, and the same are arranged and secured in a safe manner. Commanding of machine is done properly with the control board.

Drilling a hole is carried out through the drive motor with reduction gear and system for drilling with diamond tools which are mounted on a special tube. Installation and removal of diamond tools on the machine is performed. Clamping of drilling tools and installation of extensions are performed appropriately performed. Extraction of geological cores via the pneumatic system and the system of ropes and drums and are also performed in a safe manner. Monitorinf and taking the appropriate measures for cooling the drilling through cooling system that is driven by a suitable pump. Monito-ring the operation of generators to supply electricity.

Periodical jobs: If necessary, driving a motor vehicle from the place of work to the base and vice versa. 


\begin{tabular}{|c|c|c|c|c|}
\hline \multicolumn{5}{|c|}{3 PODACI O RADNOM I POMOĆNOM PROSTORU } \\
\hline \multirow{4}{*}{$\begin{array}{l}\text { 3.1 Structures: } \\
\text { 3.2 Workspace: } \\
\begin{array}{l}\text { ments of work } \\
\text { space }\end{array} \\
\end{array}$} & \multicolumn{4}{|c|}{ Bisiness premises in Bor, Danila Kiša 6/28 } \\
\hline & \multicolumn{4}{|c|}{ Actual site in the exploration area Brestovac - Metovnica } \\
\hline & \multirow{2}{*}{$\begin{array}{l}\text { 3.3.1 Elements of } \\
\text { work space }\end{array}$} & \multirow{2}{*}{$\begin{array}{l}\text { 3.3.2 Prescribed } \\
\text { requirements }\end{array}$} & \multicolumn{2}{|c|}{$\begin{array}{l}\text { 3.3.3 Assessment the state } \\
\text { of workspace }\end{array}$} \\
\hline & & & Satisfies $\checkmark$ & Unsatisfies $x$ \\
\hline \multirow{3}{*}{$\begin{array}{l}\text { 1) Size and height of } \\
\text { work premises }\end{array}$} & Free floor space & $2 \mathrm{~m}^{2}$ per worker & 1 & \\
\hline & Free air space & $10 \mathrm{~m}^{3}$ per worker & 1 & \\
\hline & Height of workroom & minimum $2.5 \mathrm{~m}$ & 1 & \\
\hline \multirow{4}{*}{ 2) Floors } & Floor level & $\begin{array}{l}\text { above the level of } \\
\text { surrounding land }\end{array}$ & I & \\
\hline & Material of floor & $\begin{array}{l}\text { resistant to abrasion, } \\
\text { water airtight }\end{array}$ & / & \\
\hline & Method of making & $\begin{array}{l}\text { flat smooth but not } \\
\text { slippery }\end{array}$ & / & \\
\hline & $\begin{array}{l}\text { Condition and } \\
\text { maintenance }\end{array}$ & regularly & / & \\
\hline \multirow{3}{*}{ 3) Walls and ceiling } & Material and making & $\begin{array}{l}\text { thermal, acoustic } \\
\text { insulation }\end{array}$ & / & \\
\hline & Processing and color & plastered and painted & 1 & \\
\hline & $\begin{array}{l}\text { Condition and } \\
\text { maintenance }\end{array}$ & $\begin{array}{l}\text { light sur- } \\
\text { face/regularly }\end{array}$ & / & \\
\hline \multirow{2}{*}{ 4) Doors } & $\begin{array}{l}\text { Opening direction } \\
\text { and width }\end{array}$ & $\begin{array}{l}\text { depending on the } \\
\text { purpose of room }\end{array}$ & / & \\
\hline & $\begin{array}{l}\text { Number and } \\
\text { arrangement }\end{array}$ & $\begin{array}{l}\text { at } 30 \text { to } 50 \mathrm{~m} \text { min one } \\
\text { door }\end{array}$ & / & \\
\hline \multirow{3}{*}{ 5) Windows } & Surface of windows & $\begin{array}{l}\min 12.5 \% \text { of floor } \\
\text { area }\end{array}$ & / & \\
\hline & $\begin{array}{l}\text { Incidence angle of } \\
\text { light }\end{array}$ & $\operatorname{minimum} 24^{\circ}$ & / & \\
\hline & $\begin{array}{l}\text { Principle and method } \\
\text { of opening }\end{array}$ & easily & / & \\
\hline \multirow{3}{*}{ 6) Heating } & Method of heating & steam heating & 1 & \\
\hline & $\begin{array}{l}\text { Arrangement of } \\
\text { heating bodies }\end{array}$ & properly & / & \\
\hline & $\begin{array}{l}\text { Condition and } \\
\text { maintenance }\end{array}$ & $\begin{array}{l}\text { according to the } \\
\text { maintenance plan }\end{array}$ & I & \\
\hline \multirow{3}{*}{ 7) Microclimate } & Room temperature & $18-22^{\circ} \mathrm{C}$ & 1 & \\
\hline & $\begin{array}{l}\text { Relative room } \\
\text { humidity }\end{array}$ & $65-80 \%$ & / & \\
\hline & Airflow speed & $\begin{array}{l}0,3 \mathrm{~m} / \mathrm{s} \\
\text { (air conditioned) }\end{array}$ & / & \\
\hline \multirow[t]{2}{*}{ 8) Lighting } & General illumination & $\begin{array}{l}\text { classic properly } \\
\text { executed }\end{array}$ & / & \\
\hline & Local illumination & not required & 1 & \\
\hline \multirow{3}{*}{ 9) Others } & Sanitary facilities & properly executed & 1 & \\
\hline & Changing rooms & not required & 1 & \\
\hline & First aid cabinet & $\begin{array}{l}\text { there is prescribed } \\
\text { equipment }\end{array}$ & / & \\
\hline $\begin{array}{l}\text { 3.4 Auxiliary work- } \\
\text { space: }\end{array}$ & \multicolumn{4}{|c|}{ / } \\
\hline 3.5 Note: & \multicolumn{4}{|c|}{ Work is performed in open space } \\
\hline
\end{tabular}




\begin{tabular}{|l|l|}
\hline 4 AVAILABLE MEANS AND EQUIPMENT FOR WORK \\
\hline 4.1 Machines & $\begin{array}{l}\text { Geological drilling machines CHRISTENSEN CS 14; } \\
\text { CHRISTENSEN CS 10; } \\
\text { CHRISTENSEN CS 14 - CE C 20; }\end{array}$ \\
\hline 4.2 Devices & Compressors, pumps, etc. \\
\hline 4.3 Facilities & $/$ \\
\hline 4.4 Installations & Compressed air \\
\hline 4.5 Tools and accessories & $\begin{array}{l}\text { Different types of tools for tightening of pipes that are used for } \\
\text { geological drilling }\end{array}$ \\
\hline 4.6 Other tools forf work & Combined passenger - freight car \\
\hline
\end{tabular}

\begin{tabular}{|l|l|}
\hline $\begin{array}{l}\text { 5 MATERIALS, RAW MATERIALS AND OTHER SUBSTANCES THAT ARE } \\
\text { USED IN THE OPERATION PROCESS }\end{array}$ \\
\hline 5.1 Materials & $\begin{array}{l}\text { Different types of raw materials such as oil and grease; } \\
\text { AMC CR650 RD }\end{array}$ \\
\hline 5.2 Raw materials & Samples of minerals obtained in geological drilling \\
\hline 5.3 Other substances & $/$ \\
\hline
\end{tabular}

\begin{tabular}{|l|l|}
\hline \multicolumn{2}{|l|}{ 6 QUALIFICATION AND TRAINING } \\
\hline 6.1 Specific professional training: & Yes, training for machine operation \\
\hline 6.2 Training for health and safety at work:: & Yes, training was carried out \\
\hline 6.3 Training for fire protection: & Yes, training was carried out \\
\hline
\end{tabular}

\begin{tabular}{|l|l|c|}
\hline $\begin{array}{l}\text { 7 EQUIPMENT AND MEANS FOR PERSONAL PROTECTION AT } \\
\text { WORK }\end{array}$ & $\begin{array}{c}\text { Score of } \\
\text { condition }\end{array}$ \\
\hline 7.1 Means for head protection: & Safety helmet & Satisfies \\
\hline 7.2 Means for body protection: & Protective suit; Protective identification vest & Satisfies \\
\hline 7.3 Means for hands protection: & Protective gloves & Satisfies \\
\hline 7.4 Means for legs protection: & $\begin{array}{l}\text { Safety shoes with steel drips; } \\
\text { Protective rubber boots with steel drips }\end{array}$ & Satisfies \\
\hline 7.5 Means for eyes protection: & Safety glasses & Satisfies \\
\hline 7.6 Means for hearing protection: & Wear ear muffs; Earplugs and others. & Satisfies \\
\hline 7.7 Equipment for safe operation: & Safety harness for working at height & Satisfies \\
\hline
\end{tabular}

\begin{tabular}{|c|c|c|c|}
\hline \multicolumn{4}{|l|}{8 WORK ORGANIZATION } \\
\hline \multicolumn{4}{|c|}{ 8.1 Conditions for entering employment: } \\
\hline Degree of education & \multicolumn{3}{|c|}{ From II to VI } \\
\hline Educational profile & \multicolumn{3}{|c|}{ All professions } \\
\hline Work experience & \multicolumn{3}{|c|}{ Preferably } \\
\hline $\begin{array}{l}\text { Special knowledge, skills and } \\
\text { ability }\end{array}$ & \multicolumn{3}{|c|}{ Ability of driving a motor vehicle } \\
\hline \multicolumn{4}{|c|}{ 8.2 General information about executors: } \\
\hline $\begin{array}{l}\text { Total number of employees at } \\
\text { the workplace/group: }\end{array}$ & $>4$ & Men: Yes & Women: No \\
\hline $\begin{array}{l}\text { Professional invalids works at } \\
\text { the workplace: }\end{array}$ & No & Men:/ & Women: / \\
\hline
\end{tabular}




\begin{tabular}{|l|l|l|l|}
\hline 8.3 General requirements of the workplace: \\
\hline \multirow{4}{*}{$\begin{array}{l}\text { Engagement according } \\
\text { to the place of activities }\end{array}$} & $\begin{array}{l}\text { In the work } \\
\text { premises }\end{array}$ & Office & $0 \%$ \\
\cline { 2 - 4 } & \multirow{2}{*}{$\begin{array}{l}\text { Work in the } \\
\text { open }\end{array}$} & Ancillary work facilities & $0 \%$ \\
\cline { 2 - 4 } & & Worksite & $100 \%$ \\
\cline { 2 - 4 } Execution of tasks & Work in shifts & Yes & $100 \%$ periodically \\
\hline & Work at night & Yes & Yes, periodically \\
\cline { 2 - 4 } & $\begin{array}{l}\text { Organizes and } \\
\text { manages }\end{array}$ & Yes & \\
\hline
\end{tabular}

9 ANALYSIS OF THE CURRENT STATE OF SAFETY AND HEALTH AT WORKPLACE

\begin{tabular}{|l|c|c|}
\hline \multirow{2}{*}{ 9.1. Element of safety at work } & \multicolumn{2}{|c|}{$\begin{array}{c}\text { 9.2. Compliancy with } \\
\text { requirements }\end{array}$} \\
\hline & Yes $\checkmark$ & No x \\
\hline $\begin{array}{l}\text { Applicable and professional findings on executed reviews and } \\
\text { testing of means for work }\end{array}$ & $\checkmark$ & \\
\hline $\begin{array}{l}\text { Applicable and professional findings on executed reviews and } \\
\text { testing the conditions of work }\end{array}$ & $\checkmark$ & \\
\hline $\begin{array}{l}\text { Reports on previous and periodical medical examinations of } \\
\text { employees }\end{array}$ & $\checkmark$ & \\
\hline Data on occupational injuries & $\checkmark$ & \\
\hline Data on occupational diseases and diseases related to work & $\checkmark$ & \\
\hline Means and equipment for personal protection at work & $\checkmark$ & \\
\hline Analysis of taken measures to prevent occupational injuries & $\checkmark$ & \\
\hline Safety instructions for work & $\checkmark$ & \\
\hline $\begin{array}{l}\text { Required documentation for use and maintenance, or packaging, } \\
\text { transportation, use, storage, destruction and others }\end{array}$ & $\checkmark$ & \\
\hline Fire protection & $\checkmark$ & \\
\hline
\end{tabular}

\begin{tabular}{|l|c|l|c|c|}
\hline 10 IDENTIFYING THE DANGERS AT WORKPLACE \\
\hline 10.1 Grouping of dangers & \multicolumn{1}{|c|}{ Subgroup of dangers } & \multicolumn{2}{|c|}{$\begin{array}{c}\text { Dangers } \\
\text { YES / NO }\end{array}$} \\
\hline Group of dangers & Code & \multicolumn{1}{|c|}{} & \\
\hline & $(01)$ & $\begin{array}{l}\text { Insufficient security due to rotating or mo- } \\
\text { ving parts, }\end{array}$ & $\checkmark$ & $\checkmark$ \\
\hline & $(02)$ & $\begin{array}{l}\text { Free movement of parts or materials that can } \\
\text { cause injury of employee, }\end{array}$ & $\checkmark$ & \\
\hline & $(03)$ & $\begin{array}{l}\text { Internal transport and movement of working } \\
\text { machines or vehicles, as well as moving } \\
\text { some equipment for work, }\end{array}$ & $\checkmark$ & \\
\hline $\begin{array}{l}\text { 1) Mechanical } \\
\text { dangers that occur } \\
\text { using the work } \\
\text { equipment such as: }\end{array}$ & $(04)$ & $\begin{array}{l}\text { Use of dangerous instruments of work which } \\
\text { can produce an explosion or fire, }\end{array}$ & $\checkmark$ & \\
\hline & $(05)$ & $\begin{array}{l}\text { Inability or limitations of timely removal } \\
\text { from the place of work, exposure to closure, } \\
\text { mechanical shock, match, etc., }\end{array}$ & $\checkmark$ & \\
\hline & $(06)$ & $\begin{array}{l}\text { Other factors that may occur as mechanical } \\
\text { sources of danger, }\end{array}$ & $\checkmark$ & \\
\hline
\end{tabular}




\begin{tabular}{|c|c|c|c|c|}
\hline \multirow{8}{*}{$\begin{array}{l}\text { 2) Dangers arising in } \\
\text { connection with the } \\
\text { characteristics of } \\
\text { the workplace, such } \\
\text { as: }\end{array}$} & $(07)$ & $\begin{array}{l}\text { Dangerous surfaces (floors and all kinds of } \\
\text { treads, surfaces with which an employee } \\
\text { comes in contact, and which have sharp edges, } \\
\text { spikes, rough surfaces, protruding parts, etc.) }\end{array}$ & $\checkmark$ & \\
\hline & $(08)$ & $\begin{array}{l}\text { Work at height or in depth, in terms of regu- } \\
\text { lations on safety and health at work. }\end{array}$ & $\checkmark$ & \\
\hline & (09) & $\begin{array}{l}\text { Work in confined, restricted or danger area } \\
\text { (between two or more fixed parts, between } \\
\text { moving parts or vehicles, work indoors, which } \\
\text { is insufficiently illuminated and ventilated,etc.) }\end{array}$ & & $x$ \\
\hline & $(10)$ & $\begin{array}{l}\text { Possibility of slipping or tripping (wet or } \\
\text { slippery surfaces), }\end{array}$ & $\checkmark$ & \\
\hline & (11) & Physical instability of workplace, & & $x$ \\
\hline & (12) & $\begin{array}{l}\text { Possible consequences or disturbances due to } \\
\text { the mandatory use of means or equipment for } \\
\text { personal protection at work, }\end{array}$ & $\checkmark$ & \\
\hline & (13) & $\begin{array}{l}\text { Impacts due to the performance of work } \\
\text { processes using inappropriate or unadjusted } \\
\text { methods, }\end{array}$ & & $x$ \\
\hline & (14) & $\begin{array}{l}\text { Other dangers that may occur in connection } \\
\text { with the characteristics of workplace and } \\
\text { work methods (using the mans and equip- } \\
\text { ment for personal protection at work that } \\
\text { burden the employee, etc.); }\end{array}$ & $\checkmark$ & \\
\hline \multirow{6}{*}{$\begin{array}{l}\text { 3) Dangers that occur } \\
\text { using electricity, } \\
\text { such as: }\end{array}$} & $(15)$ & $\begin{array}{l}\text { Risk of direct contact with parts of electrical } \\
\text { installations and equipment under voltage }\end{array}$ & & $x$ \\
\hline & (16) & Risk of indirect contact & & $x$ \\
\hline & $(17)$ & $\begin{array}{l}\text { Risk of thermal effects that are developed by } \\
\text { electrical equipment and installations (overhea- } \\
\text { ting, fire, explosion, electric arc or sparks, etc.), }\end{array}$ & & $x$ \\
\hline & $(18)$ & $\begin{array}{l}\text { Danger of local lightning strike and } \\
\text { consequences of atmospheric discharge }\end{array}$ & $\checkmark$ & $x$ \\
\hline & (19) & $\begin{array}{l}\text { Danger of harmful effects of electrostatic } \\
\text { charge, }\end{array}$ & & $x$ \\
\hline & $(20)$ & $\begin{array}{l}\text { Other dangers that may occur related to } \\
\text { the use of electricity. }\end{array}$ & & $x$ \\
\hline
\end{tabular}

\begin{tabular}{|c|c|c|c|c|}
\hline \multirow{2}{*}{\multicolumn{5}{|c|}{11 IDENTIFYING THE HAZARDS AT WORKPLACE }} \\
\hline & & & & \\
\hline Group of hazards & Code & Subgroups of hazards & \multicolumn{2}{|c|}{$\begin{array}{c}\text { Hazards } \\
\checkmark \text { YES / } \times \text { NO }\end{array}$} \\
\hline \multirow{9}{*}{$\begin{array}{l}\text { 1) Hazards arising or } \\
\text { occurring in the } \\
\text { work process, such } \\
\text { as: }\end{array}$} & (21) & $\begin{array}{l}\text { Chemical hazards, dust and fumes (inhalation, } \\
\text { ingestion, penetration into the body through the } \\
\text { skin, burns, poisoning, etc.) }\end{array}$ & $\checkmark$ & \\
\hline & (22) & Physical hazards (noise and vibration), & $\checkmark$ & \\
\hline & (23) & $\begin{array}{l}\text { Biological hazards (infections, exposure to micro- } \\
\text { organisms and allergens) }\end{array}$ & & $x$ \\
\hline & (24) & $\begin{array}{l}\text { Adverse impacts microclimate (high or low tem- } \\
\text { perature, humidity and air velocity) }\end{array}$ & & $x$ \\
\hline & $(25)$ & Inadequate - insufficient illumination, & $\checkmark$ & \\
\hline & (26) & $\begin{array}{l}\text { Harmful effects of radiation (heat, ionizing or } \\
\text { non-ionizing, laser, ultrasound), }\end{array}$ & & $x$ \\
\hline & $(27)$ & Adverse climatic effects (work outdoors), & $\checkmark$ & \\
\hline & (28) & $\begin{array}{l}\text { Hazards generated using hazardous substances in } \\
\text { the production, transport, packaging, storage or } \\
\text { destruction; }\end{array}$ & & $x$ \\
\hline & $(29)$ & $\begin{array}{l}\text { Other hazards that occur in the work process, and } \\
\text { that may be the cause of injury of the employee at } \\
\text { work, occupational disease or illnesses related to } \\
\text { work, }\end{array}$ & $\checkmark$ & \\
\hline
\end{tabular}




\begin{tabular}{|c|c|c|c|c|}
\hline \multirow{4}{*}{$\begin{array}{l}\text { 2) Hazards arising } \\
\text { from psychological } \\
\text { and psycho- } \\
\text { physiological } \\
\text { efforts related } \\
\text { causally to the } \\
\text { workplace and } \\
\text { jobs that an } \\
\text { employee } \\
\text { performs, such as: }\end{array}$} & $(30)$ & $\begin{array}{l}\text { Efforts or physical stresses (manual handling of } \\
\text { loads, pushing or pulling the loads, various long- } \\
\text { term increased physical activities and etc.), }\end{array}$ & $\checkmark$ & \\
\hline & $(31)$ & $\begin{array}{l}\text { Unphysiological position of the body (prolonged } \\
\text { standing, sitting, squatting, kneeling, etc.) }\end{array}$ & $\checkmark$ & \\
\hline & $(32)$ & $\begin{array}{l}\text { Efforts for various tasks that cause psychological } \\
\text { stresses (stress, monotony, etc.), }\end{array}$ & $\checkmark$ & \\
\hline & $(33)$ & $\begin{array}{l}\text { Responsibility in receiving and transferring of } \\
\text { information, use the appropriate knowledge and } \\
\text { skills, responsibility in rules of conduct, responsi- } \\
\text { bility for rapid changes in work procedures, work } \\
\text { intensity, spatial causality of the workplace, con- } \\
\text { flict situations, working with clients and money, } \\
\text { lack of motivation to work, responsibility in man- } \\
\text { agement, etc.; }\end{array}$ & $\checkmark$ & \\
\hline $\begin{array}{l}\text { 3) Hazards related to } \\
\text { the work organiza- } \\
\text { tion, such as: }\end{array}$ & (34) & $\begin{array}{l}\text { Overtime working hours (overtime work), shift } \\
\text { work, part-time, night work, standby in case of } \\
\text { intervention, }\end{array}$ & $\checkmark$ & \\
\hline \multirow{5}{*}{$\begin{array}{l}\text { 4) Other hazards } \\
\text { occurring at work- } \\
\text { places, such as: }\end{array}$} & $(35)$ & $\begin{array}{l}\text { Hazards caused by other persons (violence to } \\
\text { persons working at the counters, security persons, } \\
\text { etc.) }\end{array}$ & & $x$ \\
\hline & $(36)$ & Work with animals, & & $x$ \\
\hline & $(37)$ & Work in an atmosphere with high or low pre-ssure & & $x$ \\
\hline & $(38)$ & Work near water or under the water surface, & & $x$ \\
\hline & (39) & Other dangers and hazards. & & $x$ \\
\hline
\end{tabular}

\section{DETERMINING THE LIST OF DANGERS AND HAZARDS AT THE WORKPLACE}

12.1 Determined list of hazards

01.1 Danger of occupational injuries caused by rotating or moving parts of the machine for geological drilling and explorations

\begin{tabular}{|l|l}
02.1 & Danger of occupational injuries caused by movement of parts during geological drilling and
\end{tabular} explorations

03.1 Danger of occupational injuries caused by movement of machines and vehicles as well as the equipment used in geological drilling and explorations

04.1 Danger of occupational injuries caused by the use of compressors and diesel generators that produce high pressures and that can cause explosions and fires

05.1 Danger of occupational injuries caused by inability or limitations for timely removal from the place of work on the machine for geological drilling and explorations

06.1 Danger of occupational injuries caused by potential traffic accidents in the management of intermittent of passenger car or light truck on categorized and uncategorized roads and transportation of working staff from the base to the place of work and vice versa;

07.1 Danger of occupational injuries caused by the type of treads and edges, rough surfaces and protruding parts on the machines for geological drilling and explorations

08.1 Danger of occupational injuries caused by work at height in servicing and maintenance the machines for geological drilling and explorations

Danger of ocupational injuries caused by the possibility of slipping or tripping (wet or slippery surfaces) on the machines and / or explorated area on which the geological drillings are carried out 


\begin{tabular}{|l|l|}
\hline 12.1 & $\begin{array}{l}\text { Danger of occupational injuries caused by mandatory use the means or equipment for per- } \\
\text { sonal protection at work (ear muffs, goggles, gloves, etc.). }\end{array}$ \\
\hline 14.1 & $\begin{array}{l}\text { Danger of occupational injuries caused by difficulty of precision work and difficulty of } \\
\text { movement due to the mandatory use of personal protective equipment at work }\end{array}$ \\
\hline 18.1 & $\begin{array}{l}\text { Danger of occupational injuries caused by natural disasters and lightning and consequences } \\
\text { of atmospheric discharge. }\end{array}$ \\
\hline 21.1 & $\begin{array}{l}\text { 12.2 Specified list of hazards } \\
\text { work with muds containing chemicals and dusts that occur in geological drilling }\end{array}$ \\
\hline 22.1 & $\begin{array}{l}\text { Hazard on health caused by noise from the operation of diesel generators and machines for } \\
\text { geological drilling and exploration }\end{array}$ \\
\hline 25.1 & Hazard on health caused by insufficient illumination during night work \\
\hline 27.1 & $\begin{array}{l}\text { Hazard on health caused by adverse climate impacts in working outdoors during geological } \\
\text { drilling and exploration }\end{array}$ \\
\hline 29.1 & $\begin{array}{l}\text { Hazard on health caused by hazards arising from the use of oils, lubricants, diesel fuel, and } \\
\text { others. }\end{array}$ \\
\hline 30.1 & $\begin{array}{l}\text { Hazard on health caused by physical efforts and stresses during manual transfer of pipes, } \\
\text { tools and equipment for geological drilling }\end{array}$ \\
\hline 31.1 & $\begin{array}{l}\text { Hazard on health caused by non-physiological body position during prolonged standing, } \\
\text { squatting or kneeling in control and operation of machines for geological drilling and explo- } \\
\text { ration }\end{array}$ \\
\hline 32.1 & $\begin{array}{l}\text { Hazard on health caused by the efforts of psychophysical stresses in monitoring and control } \\
\text { the operation of machines for geological drilling and exploration, }\end{array}$ \\
\hline 33.1 & $\begin{array}{l}\text { Hazard on health caused by responsibility in receiving and transferring the information, } \\
\text { using the appropriate knowledge and skills to work on machines for geological drilling and } \\
\text { exploration, }\end{array}$ \\
\hline 34.1 & $\begin{array}{l}\text { Hazard on health caused by prolonged work as well as work at night for geological drilling } \\
\text { and exploration. }\end{array}$ \\
\hline
\end{tabular}

\begin{tabular}{|c|l|l|l|l|l|l|}
\hline $\mathbf{1 3}$ ASSESSMENT OF OH\&S RISK & $\begin{array}{l}\text { R- } \\
\mathbf{1 3 . 1}\end{array}$ & $\begin{array}{l}\text { Risk assessment for determined } \\
\text { specified hazards }\end{array}$ & $\mathbf{V}$ & $\mathbf{T}$ & $\mathbf{U}$ & $\begin{array}{l}\text { Specified measures } \\
\text { Risk } \\
\text { for risk assessment }\end{array}$ \\
\hline 01.1 & $\begin{array}{l}\text { Danger of occupational injuries } \\
\text { caused by rotating or moving parts } \\
\text { of the machine for geological drill- } \\
\text { ing and explorations }\end{array}$ & 6 & 3 & 6 & 108 & $\begin{array}{l}\text { Instructions for safe } \\
\text { operation in geological } \\
\text { drilling }\end{array}$ \\
\hline 02.1 & $\begin{array}{l}\text { Danger of occupational injuries } \\
\text { caused by movement of parts du- } \\
\text { ring geological drilling and explora- } \\
\text { tions }\end{array}$ & 6 & 3 & 6 & 108 & $\begin{array}{l}\text { Use of technical pro- } \\
\text { tective devices; Instruc- } \\
\text { tions for safe operation } \\
\text { in geological drilling }\end{array}$ \\
\hline 03.1 & $\begin{array}{l}\text { Danger of occupational injuries } \\
\text { caused by movement of machines } \\
\text { and vehicles as well as the equip- } \\
\text { ment used in geological drilling } \\
\text { and explorations }\end{array}$ & 3 & 3 & 6 & 54 & $\begin{array}{l}\text { Instructions for safe } \\
\text { operation in geological } \\
\text { drilling; }\end{array}$ \\
\hline
\end{tabular}




\begin{tabular}{|c|c|c|c|c|c|c|}
\hline 04.1 & $\begin{array}{l}\text { Danger of occupational injuries } \\
\text { caused by the use of compressors } \\
\text { and diesel generators that produce } \\
\text { high pressures and that can cause } \\
\text { explosions and fires }\end{array}$ & 3 & 3 & 6 & 54 & $\begin{array}{l}\text { Instructions for safe } \\
\text { operation on the ma- } \\
\text { chine }\end{array}$ \\
\hline 05.1 & $\begin{array}{l}\text { Danger of occupational injuries } \\
\text { caused by inability or limitations for } \\
\text { timely removal from the place of } \\
\text { work on the machine for geological } \\
\text { drilling and explorations }\end{array}$ & 6 & 3 & 6 & 108 & $\begin{array}{l}\text { Instructions for safe } \\
\text { operation on machines }\end{array}$ \\
\hline 06.1 & $\begin{array}{l}\text { Danger of occupational injuries } \\
\text { caused by potential traffic accidents } \\
\text { in the management of intermittent } \\
\text { of passenger car or light truck on } \\
\text { categorized and uncategorized } \\
\text { roads and transportation of working } \\
\text { staff from the base to the place of } \\
\text { work and vice versa; }\end{array}$ & 6 & 3 & 6 & 108 & $\begin{array}{l}\text { Protective measures in } \\
\text { the use of motor vehi- } \\
\text { cles }\end{array}$ \\
\hline 07.1 & $\begin{array}{l}\text { Danger of occupational injuries } \\
\text { caused by the type of treads and } \\
\text { edges, rough surfaces and protrud- } \\
\text { ing parts on the machines for geo- } \\
\text { logical drilling and explorations }\end{array}$ & 3 & 3 & 6 & 54 & $\begin{array}{l}\text { General instructions } \\
\text { for safe operation; } \\
\text { Instructions - safety } \\
\text { measures at the site }\end{array}$ \\
\hline 08.1 & $\begin{array}{l}\text { Danger of occupational injuries } \\
\text { caused by work at height in servi- } \\
\text { cing and maintenance the machines } \\
\text { for geological drilling and explora- } \\
\text { tions }\end{array}$ & 6 & 3 & 6 & 108 & $\begin{array}{l}\text { Instructions for safe } \\
\text { work at height }\end{array}$ \\
\hline 10.1 & $\begin{array}{l}\text { Danger of ocupational injuries } \\
\text { caused by the possibility of slipping } \\
\text { or tripping (wet or slippery surfa- } \\
\text { ces) on the machines and/or } \\
\text { explorated area on which the geo- } \\
\text { logical drillings are carried out }\end{array}$ & 3 & 3 & 6 & 54 & $\begin{array}{l}\text { Instructions - safety } \\
\text { measures at the site } \\
\text { Protective measures } \\
\text { against slipping, trip- } \\
\text { ping and falling }\end{array}$ \\
\hline 12.1 & $\begin{array}{l}\text { Danger of occupational injuries } \\
\text { caused by mandatory use the means } \\
\text { or equipment for personal protec- } \\
\text { tion at work (ear muffs, goggles, } \\
\text { gloves, etc.). }\end{array}$ & 3 & 3 & 6 & 54 & $\begin{array}{l}\text { Protection measures } \\
\text { in the use of PPE }\end{array}$ \\
\hline 14.1 & $\begin{array}{l}\text { Danger of occupational injuries } \\
\text { caused by difficulty of precision } \\
\text { work and difficulty of movement } \\
\text { due to the mandatory use of person- } \\
\text { al protective equipment at work }\end{array}$ & 3 & 3 & 6 & 54 & $\begin{array}{l}\text { Protection measures } \\
\text { in the use of PPE }\end{array}$ \\
\hline 18.1 & $\begin{array}{l}\text { Danger of occupational injuries } \\
\text { caused by natural disasters and } \\
\text { lightning and consequences of at- } \\
\text { mospheric discharge. }\end{array}$ & 1 & 3 & 1 & 3 & $\begin{array}{l}\text { Operating Instructions } \\
\text { for geological drillings }\end{array}$ \\
\hline
\end{tabular}




\begin{tabular}{|c|c|c|c|c|c|c|}
\hline 13.2 & $\begin{array}{c}\text { Risk assessment for determined } \\
\text { specified hazards }\end{array}$ & $\mathbf{V}$ & $\mathbf{T}$ & $\mathbf{U}$ & $\begin{array}{c}\text { R- } \\
\text { Risk }\end{array}$ & $\begin{array}{l}\text { Specified measures } \\
\text { for risk assessment }\end{array}$ \\
\hline 21.1 & $\begin{array}{l}\text { Hazard on health caused by chemi- } \\
\text { cal hazards caused by operation of } \\
\text { diesel generators, work with muds } \\
\text { containing chemicals and dusts that } \\
\text { occur in geological drilling }\end{array}$ & 6 & 3 & 6 & 108 & $\begin{array}{l}\text { Use of personal protec- } \\
\text { tive equipment }\end{array}$ \\
\hline 22.1 & $\begin{array}{l}\text { Hazard on health caused by noise } \\
\text { from the operation of diesel genera- } \\
\text { tors and machines for geological } \\
\text { drilling and exploration }\end{array}$ & 6 & 3 & 6 & 108 & $\begin{array}{l}\text { Use of personal protec- } \\
\text { tive equipment }\end{array}$ \\
\hline 25.1 & $\begin{array}{l}\text { Hazard on health caused by insuffi- } \\
\text { cient illumination during night work }\end{array}$ & 3 & 3 & 6 & 54 & $\begin{array}{l}\text { Instructions }- \text { safety } \\
\text { measures at the site }\end{array}$ \\
\hline 27.1 & $\begin{array}{l}\text { Hazard on health caused by adverse } \\
\text { climate impacts in working out- } \\
\text { doors during geological drilling and } \\
\text { exploration }\end{array}$ & 6 & 3 & 6 & 108 & $\begin{array}{l}\text { Use of personal } \\
\text { protective equipment }\end{array}$ \\
\hline 29.1 & $\begin{array}{l}\text { Hazard on health caused by hazards } \\
\text { arising from the use of oils, lubri- } \\
\text { cants, diesel fuel, and others. }\end{array}$ & 6 & 3 & 6 & 108 & $\begin{array}{l}\text { Use of personal } \\
\text { protective equipment }\end{array}$ \\
\hline 30.1 & $\begin{array}{l}\text { Hazard on health caused by physi- } \\
\text { cal efforts and stresses during man- } \\
\text { ual transfer of pipes, tools and } \\
\text { equipment for geological drilling, }\end{array}$ & 6 & 3 & 6 & 108 & $\begin{array}{l}\text { Use of personal } \\
\text { protective equipment }\end{array}$ \\
\hline 31.1 & $\begin{array}{l}\text { Hazard on health caused by non- } \\
\text { physiological body position during } \\
\text { prolonged standing, squatting or } \\
\text { kneeling in control and operation of } \\
\text { machines for geological drilling and } \\
\text { exploration, }\end{array}$ & 6 & 3 & 6 & 108 & $\begin{array}{l}\text { Use of personal } \\
\text { protective equipment }\end{array}$ \\
\hline 32.1 & $\begin{array}{l}\text { Hazard on health caused by the } \\
\text { efforts of psychophysical stresses in } \\
\text { monitoring and control the opera- } \\
\text { tion of machines for geological } \\
\text { drilling and exploration, }\end{array}$ & 3 & 2 & 6 & 36 & $\begin{array}{l}\text { Proper use the } \\
\text { prescribed work } \\
\text { breaks (daily, weekly, } \\
\text { yearly) }\end{array}$ \\
\hline 33.1 & $\begin{array}{l}\text { Hazard on health caused by respon- } \\
\text { sibility in receiving and transferring } \\
\text { the information, using the appropri- } \\
\text { ate knowledge and skills to work on } \\
\text { machines for geological drilling and } \\
\text { exploration, }\end{array}$ & 3 & 2 & 6 & 36 & $\begin{array}{l}\text { Proper use the } \\
\text { prescribed work } \\
\text { breaks (daily, weekly, } \\
\text { yearly) }\end{array}$ \\
\hline 34.1 & $\begin{array}{l}\text { Hazard on health caused by prolon- } \\
\text { ged work as well as work at night } \\
\text { for geological drilling and explora- } \\
\text { tion. }\end{array}$ & 3 & 2 & 6 & 36 & $\begin{array}{l}\text { Proper use the } \\
\text { prescribed work } \\
\text { breaks (daily) }\end{array}$ \\
\hline \multicolumn{7}{|c|}{ 13.3 Comment on assessed dangers and hazards: } \\
\hline \multicolumn{7}{|c|}{$\begin{array}{l}\text { Based on identified, analyzed and defined specific dangers and hazards at work place and working } \\
\text { environment Driller-Geological exploratory drilling, the assessed probabilities of occurrence the } \\
\text { occupational injuries, damage to health and diseases in relation to the work and assessment the se- } \\
\text { verity of injury, damage to health and diseases in relation with, the MEDIUM RISK (R III) was } \\
\text { assessed of occupational injuries, damage to health and diseases related to work. }\end{array}$} \\
\hline
\end{tabular}




\subsection{Opinion of occupational health service:}

Professional team of occupational health service has reviewed the assessed dangers and hazards for the work place Driller-Geological exploratory drilling and thinking that the indications exists for proclamation the work place with increased risk.

\subsection{The final conclusion of the Team for assessment the OH\&S risk:}

Based on the assessed specific dangers, theTeam for assessment the OH\&S risks brings:

THE FINAL CONCLUSION

For the work place Driller-Geological exploratory drilling, the RISK LEVEL R III - ME-

DIUM RISK was established for occupational injuries, damage to health and diseases in relation to the work. Based on the final conclusion on assessment the OH\&S risks, the mentioned work place is categorized as the work place with INCREASED RISK.

For establishing the mechanism of control/management with increased OH\&S risks, it is needed to define the MANAGEMENT PLAN OF ASSESSED OH\&S RISKS.

\begin{tabular}{|c|c|c|c|c|c|c|c|}
\hline \multicolumn{8}{|c|}{14 PLAN OF MANAGEMENT THE ASSESSED OH\&S RISKS } \\
\hline \multirow[b]{2}{*}{ Risk } & \multirow[b]{2}{*}{$\begin{array}{l}\text { List of increased } \\
\text { OH\&S risks for the } \\
\text { workplace driller- } \\
\text { geological } \\
\text { exploration drilling }\end{array}$} & \multicolumn{5}{|c|}{ Hierarchy of management the increased $0 H \& S$ risks } & \multirow[b]{2}{*}{ Priority } \\
\hline & & $\begin{array}{l}1 \text { Measures of } \\
\text { complete risk } \\
\text { elimination: }\end{array}$ & $\begin{array}{l}2 \text { Measure of risk } \\
\text { replacement } \\
\text { (substitution) }\end{array}$ & $\begin{array}{l}3 \text { Measures of } \\
\text { technical } \\
\text { (engineering) } \\
\text { risk control: }\end{array}$ & $\begin{array}{l}4 \text { Measures of signaling } \\
\text { the warnings or } \\
\text { administrative control } \\
\text { risk: }\end{array}$ & $\begin{array}{l}5 \text { Measures for } \\
\text { application the } \\
\text { PPE and } \\
\text { equipment for } \\
\text { BNR }\end{array}$ & \\
\hline \multirow[t]{4}{*}{108} & \multirow{4}{*}{$\begin{array}{l}\text { Risk of } \\
\text { occupational } \\
\text { injuries caused by } \\
\text { rotating or moving } \\
\text { parts of the } \\
\text { machine for } \\
\text { geological drilling } \\
\text { and exploration }\end{array}$} & Not applicable & $\begin{array}{l}\text { Mandatory } \\
\text { application the } \\
\text { technical protection } \\
\text { devices with rotating } \\
\text { or moving parts }\end{array}$ & $\begin{array}{l}\text { Mandatory } \\
\text { daily and } \\
\text { weekly } \\
\text { inspection and } \\
\text { periodic testing }\end{array}$ & $\begin{array}{l}\text { Mandatory application } \\
\text { the procedures, } \\
\text { instructions. } \\
\text { Mandatory rraining for } \\
\text { safe operation. } \\
\text { Mandatory periodic } \\
\text { medical examination }\end{array}$ & $\begin{array}{l}\text { Mandatory use } \\
\text { of personal } \\
\text { protective } \\
\text { equipment and } \\
\text { equipment for } \\
\text { safe operation }\end{array}$ & High \\
\hline & & & & & & & \\
\hline & & & & & & & \\
\hline & & & & & & & \\
\hline 108 & $x$ & & & & & & \\
\hline 54 & $y$ & & & & & & \\
\hline 36 & $z$ & & & & & & \\
\hline
\end{tabular}

\section{CONCLUSION}

Institutional changes that have occurred in the Republic of Serbia in the field of health and safety at work have inevitably caused the need for development and improvement of tools for decision making in planning and management the system of health and safety at work. Making decisions based on the previously presented models and methods of assessment the OH\&S risks is a flexible approach that is proactive and provides identification, determining the prio-rities and documentation on $\mathrm{OH} \& \mathrm{~S}$ risks, as well as implementation the Plan of measures for control the assessed OH\&S risks.

Based on a detailed identification and hazard analysis of dangers and hazards for the work place Driller - geological exploratory drilling in the organization "Geops Balkan Drilling Services" Ltd., it can be concluded that the optimized method Kinny and methodological approach to the assessment OH\&S risks has fulfilled its purpose and gave the satisfactory results. 
Management of OH\&S risks in accordance with this methodological approach is very reliable and useful tool for decision makers in fulfilling the policy and objectives in terms of health and safety at work.

The optimized model of assessment the OH\&S risks based on the Kinny method, applied in this paper, is practically tested in the other similar organizations such as: Drillex International Ltd., International Drilling Service Ltd. and Stara Planina Resources Ltd. Based on this model, the efficient and effective management of occupational health and safety at work was established in accordance with SRPS OHSAS 18001: 2008.

From practical application the optimized model for assessment the OH\&S risks in management of $\mathrm{OH} \& \mathrm{~S}$ system, it can be concluded that in the most stages of geological exploratory drilling the increased $\mathrm{OH} \& \mathrm{~S}$ risk is present, but that the same can be managed only if the planned measures are applied under the Plan of measures to control the assessed OH\&S risks.

Thus proposed methodological procedure for assessment the OH\&S risks can be of great use to the other organizations that use this method of risk assessment or deal with similar activities. Assessment of $\mathrm{OH} \& \mathrm{~S}$ risks and establishing the control mechanisms of management is of great use in a system design of management the occupational health and safety at work. The proposed valuation model of $\mathrm{OH} \& \mathrm{~S}$ risksenables that the information about $\mathrm{OH} \& \mathrm{~S}$ risk are adequately processed and use in decision making at the relevant levels of the organization dealing with works on geological exploratory drillings.

Active and comprehensive assessment of OH\&S risk as it is defined in this paper, the management organization that deals with geological exploratory drillings can:
- accept and approve the management policy by assessed OH\&S risk;

- inform all stakeholders in the process of geological exploratory drillings;

- define the mechanisms of control the assessed $\mathrm{OH} \& \mathrm{~S}$ risks that correspond to the performances of organization;

- provide the compliance with legal regulations and subordinate legilastion as well as the legal acts of organization;

- provide the distribution of needed resources for managing theassessed $\mathrm{OH} \& \mathrm{~S}$ risk.

\section{REFERENCES}

[1] Anderson, K. "Intelligence - Based Threat Assessments for Information Networks and Infrastructures: A White Paper", 2005;

[2] Commoner B.; "Comparing Apples to Oranges: Risk of Cost/Benefit Analysis" from Contemporary Moral Controversies in Technology, A. P. Iannone, ed., pp. 64-65;

[3] Lerche, I. (Ian) Environmental Risk Assessment: Quantitative Measures, Anthropogenic Influences, Human Impact. Berlin: Springer, 2006;

[4] Staletović N.; Assessment the OHS Risks in a Function of preventive Engineering and Integrated Management Systems (QMS, EMS i OHSAS); Tehnika No. 59(2009)3, pp. 8-14; Belgrade;

[5] Staletović N., Tucović N.; Management of Preventive Engineering Aspects in Constreuction; "IMK - 14 Istraživanje i razvoj"; Kruševac 2009;

[6] Staletović, N., Andjelković, B., Development of Technological Systems and Preventive Engineering, „Ekologica”, Belgrade, No. 2. 2000, pp. 98-103; 
[7] Standard ISO 31010:2010 Risk Management - Risk Assessment Techniques;

[8] Standards Australia and Standards New Zealand; Standard Risk Management AS/NZS 4360:2009. Sydney and Wellington: Standards Australia and Standards New Zealand;

[9] Standard SRPS OHSAS 18001: 2008 Management System of Health Protection and Safety at Work-Requirements;

[10] Antić R., Staletović N.; Kovačević S.; Act on Risk Assessment at the Work Place and Working Environment "Geops Balkan Driling Services" d.o.o; MIN Institut a.d. Niš; 2013;
[11] Staletović N.; Kovačević S., Kovačević M.; Tucović N.: Methodological Framework of Risk Assessment in a Function of Maintenance the Mining Equipment and Management of (QMS, AMS, EMS i OHSAS) in the Mining Companies; Mining and Metallurgy Engineering Bor, 3(2013), pp.135-146.

[12] Staletović N.; Kovačević K., Kovačević M.; Methodological Approach to the Identification and Environmental Impact Assessment for the Project "Magnesite Mining in the Deposit Čavlovac - Masnica"; Mining Engineering 3/2012, pp. 183-194. 


\begin{tabular}{ll}
\hline \hline INSTITUT ZA RUDARSTVO I METALURGIJU BOR & ISSN: 2334-8836 \\
& UDK: 622 \\
\hline \hline
\end{tabular}

Novica Staletović ${ }^{*}$ Srđa Kovačević ${ }^{* *}$, Miša Kovačević ${ }^{* * *}$

\section{RAZVOJ MODELA PROCENE OH\&S RIZIKA ZA RADNO MESTO BUŠAČ U PROCESU IZVOĐENJA GEOLOŠKIH ISTRAŽNIH BUŠENJA}

Izvod

U radu je kreiran model procene OH\&S rizika za radno mesto bušač u procesu izvođenja geoloških istražnih radova. Model procene OH\&S rizika za radno mesto bušač bazira se na standardu ISO 31010 $i$ ispunjenju zahteva standarda OHSAS 18001 i zakonske regulative. U ovom slučaju korišćena je delimično prilagođena i optimizovana Kinny metoda. Model procene OH\&S rizika daje realne osnove za razvoj $i$ implementaciju sistema menadžmenta zaštite zdravlja i bezbednosti na radu u skladu sa SRPS OHSAS 18001:2008, s obzirom da je praktično primenjen i proveren u organizacijama koje se bave geološkim istražnim bušenjima kao što su "Geops Balkan Driling Services" d.o.o, Drillex International d.o.o, International Drilling Service d.o.o kao i Stara Planina Resources d.o.o

Ključne reči: OH\&S rizik, bušač, geologija, istražna bušenja

\section{UVOD}

Bezbednost i zdravlje na radu je veoma značajan segment rada kod svakog poslodavca - bez obzira na vrstu delatnosti koju poslodavac obavlja. Sistemskim pristupom bezbednosti i zdravlja na radu daje se značaj prevenciji u svim fazama rada. Procenom $\mathrm{OH} \& \mathrm{~S}$ rizika teži se kontrolisanju rizika radi otklanjanja opasnosti i štetnosti od povreda na radu, profesionalnih oboljenja i oboljenja $\mathrm{u}$ vezi sa radom i da bi se uspostavio sistem upravljanja zaštitom zdravlja i bezbednošću na radu (OHSAS). Postizanje kvaliteta $\mathrm{u}$ upravljanju sistemom zaštite zdravlja i bezbednosti na radu nije moguće bez usklađivanja sa osnovnim zakonskim obavezama procene $\mathrm{OH} \& \mathrm{~S}$ rizika.

Organizacije čija je delatnost geološko istražno bušenje za očekivati je da će se suočiti sa značajnim OH\&S rizicima. Ukoliko $\mathrm{OH} \& \mathrm{~S}$ rizici nisu adekvatno procenjeni i stavljeni pod konrolom mogu u negativnom smislu uticati na ostvarivanje ciljeva organizacije. Ciljevi organizacije se mogu odnositi na niz aktivnosti, od strateških inicijativa pa sve do operacija, a mogu se ogledati i u neusaglašenostima sa zakonskom regulativom $\mathrm{i}$ drugim zahtevima. $\mathrm{S}$ obzirom, da se tehnološki proces geoloških istražnih bušenja sastoji od operacija u kojima učestvuje značajan broj opasnih materija to potencijalni $\mathrm{OH} \& \mathrm{~S}$ rizici mogu biti i veći.

Upravljanje OH\&S rizikom podrazumeva primenu logičkih i sistematskih metoda za identifikaciju, analizu i procenu $\mathrm{OH} \& \mathrm{~S}$ rizika tokom procesa geoloških

\footnotetext{
* Fakultet za ekologiju i zaštitu životne sredine Beograd, e-mail: nomstale@open.telekom.rs ** JPPK „Kosovo” Obilić, e-mail: srdja.kovacevic@sbb.rs

*** YUQS,Trg Nikole Pašića 3/I, Beograd; e-mail: kovacevicmisa90@gmail.com
} 
istražnih bušenja, praćenje i preispitivanje rizika u cilju efektivnog i efikasnog upravljanja integrisanim sistemima menadžmenta kvalitetom (ISO 9001), zaštitom životne sredine (ISO 14001) i zaštitom zdravlja i bezbednosti na radu (OHSAS 18001).

Cilj ovog istraživanja je procena $\mathrm{OH} \& \mathrm{~S}$ rizika u procesu geološkog istražnog bušenja uz pronalaženje odgovora na sledeća osnovna pitanja:

- Šta se u procesu geoloških istražnih bušenja može desiti i zašto (identifikacija opasnosti)?

- Koje su to verovatnoće pojave opasnosti i štetnosti?

- Da li se procenjenim OH\&S rizicima može upravljati i da li se zahteva dalji tretman smanjenja OH\&S rizika?

- Kako izvršiti planiranje mera zaštite zdravlja i bezbednosti na radu koje mogu da utiču na smanjenje verovatnoće pojave opasnosti i štetnosti?

U skladu sa utvrđenim ciljem istraživanja, postavljena je se sledeća hipoteza istraživanja:

a) $\mathrm{Na}$ osnovu sistemskog pristupa moguće je izvršiti identifikaciju, analizu opasnosti i procenu OH\&S rizika i uspostaviti mehanizme za kontrolu procenjenih $\mathrm{OH} \& \mathrm{~S}$ rizika.

$\mathrm{Na}$ osnovu identifikacije problema, postavljenog cilja i hipoteze istraživanja proistekli su sledeći zadaci istraživanja i to:

1) izvršiti sistemsku analizu, i definisati model i metodu procene $\mathrm{OH} \& \mathrm{~S}$ rizika;

2) izvršiti identifikaciju opasnosti, utvrditi verovatnoću pojave i potencijalnih posledica;

3) izvršiti procenu $O H \& S$ rizika za konkretno radon mesto.

4) definisati Plan mera za kontrolu povećanih $\mathrm{OH} \& \mathrm{~S}$ rizika.

U cilju ispunjenja zadataka istraživanja i postizanja cilja i provere postavljene hipoteze istraživanja korišćene su poznate metode koje su doprinele poboljšanju metodologiji istraživanja, a to su:
1) deskriptivna metoda (metoda zapažanja i opisivanja) kroz analizu dostupnih podataka;

2) metoda analize teorije i prakse;

3) metoda opšte teorije sistema odnosno sistemskoh pristupa i sistemske analize;

4) metoda modeliranja procesa, i izrade dijagrama toka.

\section{TEORIJSKI PRISTUP, IZABRANI METODOLOŠKI POSTUPAK I METODA PROCENE OH\&S RIZIKA}

\subsection{Teorijski pristup procene $\mathrm{OH} \& S$ rizika}

Da bi se ispunili zahtevi standarda OHSAS 18001 kao i zahtevi zakonske regulative potrebno je da za sve opasnosti i štetnosti koje se javljaju i/ili se mogu javiti na radnom mestu bušač u procesu geoloških istražnih bušenja izvrši procena $\mathrm{OH} \& \mathrm{~S}$ rizika. Radi efektivne i efikasne procene OH\&S rizika, neophodno je koristiti odgovarajuću metodu koja će dati proaktivne, a ne reaktivne rezultate procene [10]. Efektivnost $\mathrm{i}$ efikasnost $\mathrm{OH} \& \mathrm{~S}$ sistema se ne može postići samo procenom $\mathrm{OH} \& \mathrm{~S}$ rizika, već je neophodno da nakon izvršene procene $\mathrm{OH} \& \mathrm{~S}$ rizika organizacija obezbediti uslove da se rezultati procene $\mathrm{OH} \& S$ rizika uzmu u obzir prilikom uspostavljanja $\mathrm{OH} \& \mathrm{~S}$ sistema i definiše plan upravljanja povećanih $\mathrm{OH} \& \mathrm{~S}$ rizicima.

U svetu, a i u R. Srbiji je najčešće upotrebljeni alat za uspostavljanje, održavanje i unapređivanje sistema upravljanja zaštitom zdravlja i bezbednošću na radu standard OHSAS 18001. OH\&S sistem je strukturiran proces za savlađivanje $\mathrm{OH} \& S$ rizika. Navedenim standardom su precizno dati zahtevi nekih ključnih elemenata sistema upravljanja zaštitom zdravlja i bezbednošću na radu kao što su: prepoznavanje opasnosti i štetnosti koje mogu nastati gde se obavezno uzimaju u obzir ponašanja i sposobnosti zaposlenih, vođenje, komunikacija, sarađivanje i savetovanje sa zaposlenima. 
Upravljati OH\&S rizicima znači pronaći onu prihvatljivu kombinaciju koja omogućava akcije povećanja bezbednosti i zdravlja na radu i otklanjanja svih opasnosti i štetnosti koje dovode u pitanje optimalno funkcionisanje $\mathrm{OH} \& \mathrm{~S}$ sistema. Upravljanje $\mathrm{OH} \& \mathrm{~S}$ rizicima moguće je ostvariti uz pretpostavke koje podrazumevaju sledeće:

- pravovremeno identifikovanje svih opasnosti i štetnosti;

- utvrđivanje liste opasnosti i štetnosti koje imaju uticaj na OH\&S sistem;

- analiza ranijih podataka o posledicama nastanka povreda na radu, profesionalnih oboljenja i oboljenja u vezi sa radom;

- analiza pojedinačnih opasnosti i štetnosti njihovo grupisanje po srodnosti;

- analiza međuzavisnosti pojedinačnih opasnosti i štetnosti i njihovih eventualnih posledica;

- procena OH\&S rizika za utvrđenu listu opasnosti i štetnosti;
- formiranje okruženja koje neguje tradiciju timskog rada;

- razvoj metoda i tehnika za procenu i upravljanjeOH\&S rizicima;

- uspostavljanje optimalnog nivoa bezbednosti na radu;

- donošenje ciljeva, planova i programa za upravljanje procenjenim OH\&S rizicima.

Za efikasnu kontrolu OH\&S rizika, potrebno je znati upravljati informacijama na osnovu kojih se donose zaključci i odluke, tj. potrebno je obratiti pažnju na kvalitet informacija kojima se raspolažu iz Akta o proceni OH\&S rizika.

Procena $\mathrm{OH} \& \mathrm{~S}$ rizika u poslovnom procesu nije ni u kom slučaju neka konstanta, već dinamička veličina koja se menja od trenutka do trenutka. Svaki puta kada se promeni neki od elemenata opasnosti i štetnosti, menja se i nivo $\mathrm{OH} \& \mathrm{~S}$ rizika. Postoji standard koji definiše proces procene rizika ISO 31010: 2010 [8].

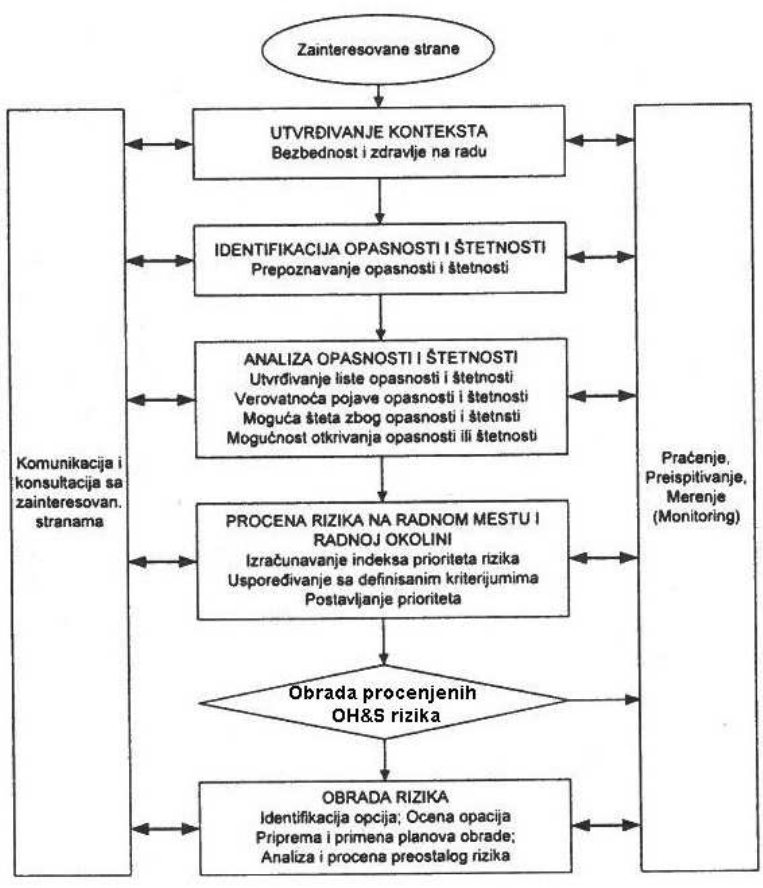

SI. 1. Blok dijagram procesa procene OH\&S rizika[8], [12] 


\subsection{Izabrana metoda procene OH\&S rizika}

Jedna od metoda kojom je moguće izvršiti procenu $\mathrm{OH} \& S$ rizika je Kinny metoda. $\mathrm{OH} \& \mathrm{~S}$ rizici se tokom vremena menjaju kroz tri osnovne kategorije koje analizira metoda Kinny i to:

- verovatnoća pojave opasnosti i štetnosti;

- težina posledica koje mogu nastati kod pojave opasnosti i štetnosti;

- učestalost pojavljivanja opasnosti i štetnosti.

$\mathrm{Na}$ osnovu identifikacije opsanosti štetnosti na radnom mestu $\mathrm{i}$ radnoj okolini $\mathrm{i}$ statističke obrade podataka o opasnim događajima (povredama na radu), opasnim materijama i kritičnim tačkama procesa može se izvršiti procena $\mathrm{OH} \& \mathrm{~S}$ rizika.

Postupkom identifikacije opasnosti i štetnosti i vrednovanja uticaja postiže se sledeće:

- identifikuju se sve opasnosti i štetnosti koje mogu imati uticaja na radno mesto i radnu okolinu;

- analiziraju se uticaji opasnosti i štetnosti na radno mesto i radnu okolinu;

- utvrđuje se sistem vrednovanja svake opasnosti i štetnosti;

- određivanja značaja svake opasnosti i štetnosti.

Parametri analize se numerički vrednuju, pa je i konačna procena $\mathrm{OH} \& S$ rizika na radnom mestu i radnoj okolini izražena numerički. Osnovna postavka metode Kinny $\mathrm{u}$ funkciji procene rizika na radnom mestu i radnoj okolini je u suštini jednostavna i laka za razumevanje. Suština metode sastoji se u realizaciji sledećih aktivnosti:

a) utvrđivanje svih potencijalnih opasnosti i štetnosti koje su/ili mogu nastati kao posledica procesa rada;

b) utvrđivanje mogućih uzroka nastanka svake opasnosti i štetnosti;

c) analiza svake opasnosti i štetnosti sa ciljem da se analitičkim metodama utvrde:

- verovatnoća pojave potencijalne opasnosti i štetnosti;

- težina posledica koje koje zaposleni trpi kod pojave opasnosti i štetnosti;

- učestalost pojavljivanja opasnosti i štetnosti.

d) vrednovanje nivoa rizika čine proizvod tri faktora i to:

- verovatnoća pojave opasnosti i štetnosti - V;

- težina posledice zbog pojave opasnosti i štetnosti - P;

- učestalost pojavljivanja opasnosti i štetnosti - U;

Vrednovanje rizika $\mathbf{R}$ vrši se po formuli:

$\mathbf{R}=\mathbf{V} \times \mathbf{P}$

Tabela 1. Matrica procene rizika po Kinny metodi [11]

\begin{tabular}{|c|c|c|c|}
\hline \multirow{2}{*}{ Identifikovana opasnost ili štetnost } & \multicolumn{3}{|c|}{ PROCENA OH\&S RIZIKA $R=V \times P$} \\
\hline & Verovatnoća V & Posledica P & Nivo rizika $R$ \\
\hline $\mathrm{x}$ & & & \\
\hline $\mathrm{y}$ & & & \\
\hline $\mathrm{z}$ & & & \\
\hline
\end{tabular}




\subsubsection{Kriterijum za procenu verovatnoće - $V$}

Tabela 2. Opis kriterijuma za procenu verovatnoće pojave opasnosti i štetnosti [11]

\begin{tabular}{|c|l|}
\hline RANG & \multicolumn{1}{|c|}{ OPIS KRITERIJUMA ZA PROCENU VEROVATNOĆE - V } \\
\hline $\mathbf{0 , 1}$ & Jedva pojmljivo \\
\hline $\mathbf{0 , 2}$ & Praktično neverovatno \\
\hline $\mathbf{0 , 5}$ & Postoji, ali samo malo verovatno \\
\hline $\mathbf{1}$ & Mala verovatnoća, ali moguća u ograničenim slučajevima \\
\hline $\mathbf{3}$ & Malo moguće \\
\hline $\mathbf{6}$ & Sasvim moguće \\
\hline $\mathbf{1 0}$ & Predvidivo, očekivano \\
\hline
\end{tabular}

\subsubsection{Kriterijum za procenu posledica - $P$}

Tabela 3. Opis kriterijuma za procenu posledica kod pojave opasnosti i štetnosti [11]

\begin{tabular}{|c|l|}
\hline RANG & \multicolumn{1}{|c|}{ OPIS KRITERIJUMA ZA PROCENU POSLEDICA - P } \\
\hline $\mathbf{1}$ & Bolest, povreda koja zahteva prvu pomoć i nikakav drugi tretman \\
\hline $\mathbf{2}$ & Medicinski tretman od strane lekara \\
\hline $\mathbf{3}$ & $\begin{array}{l}\text { Ozbiljne-invalidnost, ozbiljna pojedinačna povreda sa hospitalizacijom } i \\
\text { izgubljenim danima }\end{array}$ \\
\hline $\mathbf{6}$ & Veoma ozbiljne-pojedinačne nesreće sa smrtnim ishodom \\
\hline $\mathbf{1 0}$ & Katastrofalne-sa višestrukim smrtnim ishodima \\
\hline
\end{tabular}

\subsubsection{Kriterijum za procenu učestalosti} pojavljivanja opasnosti i štetnosti - $U$

Tabela 4. Opis kriterijuma za procenu učestalost pojavljivanja opasnosti i štetnosti [11]

\begin{tabular}{|c|l|}
\hline RANG & \multicolumn{1}{|c|}{ OPIS KRITERIJUMA ZA UČESTALOST - U } \\
\hline $\mathbf{1}$ & Izlaže se retko (godišnje) \\
\hline $\mathbf{2}$ & Izlaže se mesečno \\
\hline $\mathbf{3}$ & Izlaže se nedeljno \\
\hline $\mathbf{6}$ & Izlaže se dnevno \\
\hline $\mathbf{1 0}$ & Izlaže se trajno, kontinualno \\
\hline
\end{tabular}




\subsubsection{Kriterijumi za klasifikaciju}

nivoa rizika $(R)$

Tabela 5. Kriterijumi za određivanje nivoa rizika [11]

\begin{tabular}{|c|c|c|c|}
\hline $\begin{array}{c}\text { Ukupna } \\
\text { ocena }\end{array}$ & $\begin{array}{l}\text { Klasa } \\
\text { rizika }\end{array}$ & $\begin{array}{c}\text { Klasifikacija } \\
\text { nivoa rizika }\end{array}$ & Opis klasifikacije nivoa rizika \\
\hline$>0,1<20$ & R I & $\begin{array}{c}\text { Zanemarljivo } \\
\text { mali rizik }\end{array}$ & Ne zahteva se nikakva akcija. \\
\hline$>\mathbf{2 0}<\mathbf{7 0}$ & R II & Mali rizik & $\begin{array}{l}\text { Nema potrebe za dodatnim aktivnostima pri } \\
\text { upravljanju operacijom. } \\
\text { Može se razmotriti ekonomski isplativije rešenje ili } \\
\text { unapređenje bez dodatnih ulaganja. Potrebno je } \\
\text { pratiti situaciju, kako bi posedovali informacije o } \\
\text { sprovođenju propisanih aktivnosti. }\end{array}$ \\
\hline$>\mathbf{7 0}<\mathbf{2 0 0}$ & III & Srednji rizik & $\begin{array}{l}\text { Potrebno je uložiti napor kako bi se smanjio rizik, } \\
\text { ali troškovi prevencije moraju biti pažljivo } \\
\text { planirani i ograničeni do izvesnog nivoa. } \\
\text { Potrebno je definisati rok za sprovođenje } \\
\text { unapređenja. } \\
\text { Kod onih događaja kod kojih mogu nastupiti } \\
\text { izuzetno opasne posledice, potrebno je dodatno } \\
\text { proveriti verovatnoću nastanka takvog događaja } \\
\text { kako bi se definisao potreban nivo aktivnosti na } \\
\text { ublažavanju rizika. }\end{array}$ \\
\hline$>\mathbf{2 0 0}<\mathbf{4 0 0}$ & R IV & Veliki rizik & $\begin{array}{l}\text { Ne sme se započeti sa datom aktivnošću dok } \\
\text { nivo rizika ne bude snižen. } \\
\text { Potrebna su znatna sredstva kako bi se rizik } \\
\text { smanjio. } \\
\text { Ako se rizik odnosi na sve započete aktivnosti, } \\
\text { potrebno je preduzeti hitne akcije na smanjenju } \\
\text { nivoa rizika. }\end{array}$ \\
\hline$>400<1000$ & $\mathbf{R} \mathbf{V}$ & $\begin{array}{l}\text { Ekstremno } \\
\text { veliki rizik }\end{array}$ & $\begin{array}{l}\text { Aktivnost ne sme biti započeta ni nastavljena, sve } \\
\text { dok se nivo rizika ne smanji na prihvatljivi nivo. } \\
\text { Ako ulaganjem ograničenih sredstava nije moguce e } \\
\text { smanjiti nivo rizika na prihvatlïv nivo, aktivnost } \\
\text { mora ostati zabranjena. }\end{array}$ \\
\hline
\end{tabular}

\subsubsection{Kategorizacija i karakterizacija rizika}

Tabela 6. Kriterijumi za kategorizaciju i karakterizaciju rizika [11]

\begin{tabular}{|c|c|c|}
\hline Procena nivoa rizika & Kategorizacija nivoa rizika & Karakterizacija rizika \\
\hline R I & Zanemarljivo mali rizik & Prihvatljiv rizik \\
\hline R II & Mali rizik & Prihvatljiv rizik \\
\hline R III & Srednji rizik & Povećani rizik \\
\hline R IV & Veliki rizik & Neprihvatljiv rizik \\
\hline R V & Ekstremno veliki rizik & Neprihvatljiv rizik \\
\hline
\end{tabular}


Tabela 7. Opis karakterizacije rizika [11]

\begin{tabular}{|c|c|}
\hline Karakter rizika & Opis karakterizacije rizika \\
\hline Prihvatljiv rizik & $\begin{array}{l}\text { Rizik za koji postoji procena i pretpostavka da neće uzrokovati: } \\
\text { - } \quad \text { povrede na radu i oboljenja u vezi sa radom, } \\
\text { - neusaglašenost sa zakonskom regulativom i/ili odstupanje od } \\
\text { propisane organizacije rada } i \\
\text { - odstupanje od propisane politike sistema zaštite zdavlja i bezbednosti } \\
\quad \text { na radu u organizaciji. }\end{array}$ \\
\hline Povećani rizik & $\begin{array}{l}\text { Rizik za koji postoji procena i pretpostavka da u određenim okolnostima } \\
\text { može uzrokovati: } \\
\text { - povrede na radu i oboljenja u vezi sa radom, } \\
\text { - } \quad \text { delimičnu neusaglašenost sa zakonskom regulativom i/ili odstupanje } \\
\text { od propisane organizacije rada } i \\
\text { - povremeno odstupanje od propisane politike i ciljeva sistema zaštite } \\
\text { zdavlja i bezbednosti na radu. }\end{array}$ \\
\hline Neprihvatljiv rizik & $\begin{array}{l}\text { Rizik za koji postoji procena i pretpostavka da direktno uzrokuje: } \\
\text { - } \quad \text { povrede na radu i oboljenja u vezi sa radom, } \\
\text { - neusaglašenost sa zakonskom regulativom; } \\
\text { - odstupanje od propisane organizacije rada } i \\
\text { - odstupanje od propisane politike i ciljeva sistema zaštite zdravlja } i \\
\quad \text { bezbednosti na radu. }\end{array}$ \\
\hline
\end{tabular}

\section{REZULTATI ISTRAŽIVANJA - \\ PRAKTIČAN PRIMER PROCENE OH\&S RIZIKA}

\begin{tabular}{|c|c|c|}
\hline Šifra r.m. & \multirow{2}{*}{\multicolumn{2}{|c|}{$\begin{array}{l}\text { PREPOZNAVANJE I UTVRĐIVANJE OPASNOSTI I ŠTETNOSTI } \\
\text { I PROCENA RIZIKA NA RADNOM MESTU: } \\
\text { BUŠAČ - GEOLOŠKIH ISTRAŽNIHBUŠENJA }\end{array}$}} \\
\hline III GRUPA & & \\
\hline \multicolumn{3}{|c|}{ 1. OPŠTI PODACI O RADNOM MESTU } \\
\hline \multicolumn{2}{|c|}{ 1.1. Naziv radne organizacije: } & "GEOPS BALKAN DRILING SERVICES" D.O.O \\
\hline \multicolumn{2}{|l|}{ 1.2. Sektor: } & Izvođenje geoloških istražnih bušenja \\
\hline \multicolumn{2}{|l|}{ 1.3. Služba: } & / \\
\hline \multicolumn{2}{|l|}{ 1.4. Odeljenje: } & / \\
\hline
\end{tabular}

\section{PODACI O PROCESU RADA:}

\subsection{Poslovi po sistematizaciji poslova i radnih zadataka (opis poslova):}

Bušač - geoloških istražnih bušenja:

Izvode se radovi primenom odgovarajućih mašina i metoda za istraživanje mineralnih sirovina. Vrše se bušenja na geološki ispitanim područjima u cilju pronalaženja čvrstih mineralnih sirovina. Mašina za istražna bušenja je montirana na specijalnom vozilu sa gusenicama na kome su postavljeni svi radni i pogonski delovi mašine, a isti su rasporedjeni i učvršćeni na bezbedan način. Komandovanje mašinom se vrši na odgovarajući način sa komandnog pulta.

Bušenje rupa se izvodi preko pogonskog motora sa reduktorom i sistema za bušenje sa dijamantskim alatima koji se montiraju na specijalnim cevima. Vrši se montaža i demontaža dijamantskih alata na mašini. Vrši se učvršćivanje alata za bušenje i spajanje nastavaka na odgovarajući način. Vrši vadjenje uzoraka geoloških jezgara preko pneumatskih sistema $\mathrm{i}$ sistema užadi i doboša $\mathrm{i}$ isto se izvodi na bezbedan način. Nadgleda i preduzima odgovarajuće mere na hladjenju alata za bušenje preko sistema za hladjenje koji se pogoni preko odgovarajuće pumpe. Vrši se nadgledanje rada agregata za snabdevanje električnom energijom.

Povremeni poslovi: Po potrebi upravlja motornim vozilom od mesta rada do baze i obratno. 


\begin{tabular}{|c|c|c|c|c|}
\hline \multicolumn{5}{|c|}{ 3. PODACI O RADNOM I POMOĆNOM PROSTORU } \\
\hline 3.1. Objekti: & \multicolumn{4}{|c|}{ Poslovni prostor u Boru, ul. Danila Kiša 6/28 } \\
\hline 3.2. Radni prostor: & \multicolumn{4}{|c|}{ Aktuelno radilište na istražnom prostoru Brestovac - Metovnica } \\
\hline \multirow{2}{*}{$\begin{array}{l}\text { 3.3. Grupa elemenata } \\
\text { radnog prostora }\end{array}$} & \multirow{2}{*}{$\begin{array}{l}\text { 3.3.1. Elementi } \\
\text { radnog prostora }\end{array}$} & \multirow{2}{*}{$\begin{array}{l}\text { 3.3.2. Propisani } \\
\text { zahtevi }\end{array}$} & \multicolumn{2}{|c|}{$\begin{array}{c}\text { 3.3.3. Ocena stanja radnog } \\
\text { prostora }\end{array}$} \\
\hline & & & $\begin{array}{c}\text { Zadovoljava } \\
\checkmark\end{array}$ & $\begin{array}{c}\text { Ne zadovolja. } \\
x\end{array}$ \\
\hline \multirow{3}{*}{$\begin{array}{l}\text { 1) Veličina i visina } \\
\text { radne prostorije }\end{array}$} & $\begin{array}{l}\text { Slobodna površina } \\
\text { poda }\end{array}$ & $2 \mathrm{~m}^{2}$ po radniku & / & \\
\hline & $\begin{array}{l}\text { Slobodan vazdušni } \\
\text { prostor }\end{array}$ & $10 \mathrm{~m}^{3}$ po radniku & l & \\
\hline & Visina radne prostorije & $\min .2,5 \mathrm{~m}$ & 1 & \\
\hline \multirow{4}{*}{ 2) Podovi } & Nivo poda & $\begin{array}{l}\text { iznad nivoa } \\
\text { okolnog zemljišta }\end{array}$ & / & \\
\hline & Materijal poda & $\begin{array}{l}\text { otporan na } \\
\text { habanje, vodonep. }\end{array}$ & / & \\
\hline & Način izrade & $\begin{array}{l}\text { ravan gladak ali ne } \\
\text { klizav }\end{array}$ & / & \\
\hline & Stanje i održavanje & redovno & 1 & \\
\hline \multirow{3}{*}{ 3) Zidovi i plafon } & Materijal i izvođenje & $\begin{array}{l}\text { toplotna, zvučna } \\
\text { zaštita }\end{array}$ & / & \\
\hline & Obrada i boja & $\begin{array}{l}\begin{array}{l}\text { malterisano i } \\
\text { obojeno }\end{array} \\
\end{array}$ & / & \\
\hline & Stanje i održavanje & $\begin{array}{l}\text { svetla površina / } \\
\text { redovno }\end{array}$ & / & \\
\hline \multirow{2}{*}{ 4) Vrata } & $\begin{array}{l}\text { Smer otvaranja i } \\
\text { širina }\end{array}$ & $\begin{array}{l}\text { u zavisn. od } \\
\text { namene prostor. }\end{array}$ & / & \\
\hline & Broj i raspored & $\begin{array}{l}\text { na } 30 \text { do } 50 \mathrm{~m} \\
\text { min jedna vrata }\end{array}$ & / & \\
\hline \multirow{3}{*}{ 5) Prozori } & $\begin{array}{l}\text { Površina prozorskih } \\
\text { otvora }\end{array}$ & $\begin{array}{l}\min 12,5 \% \\
\text { površine poda }\end{array}$ & l & \\
\hline & Upadni ugao svetla & $\min 24^{0}$ & 1 & \\
\hline & $\begin{array}{l}\text { Princip i način } \\
\text { otvaranja }\end{array}$ & sa lakoćom & / & \\
\hline \multirow{3}{*}{ 6) Zagrevanje } & Način zagrevaja & parno grejanje & 1 & \\
\hline & Raspored grejnih tela & propisno & 1 & \\
\hline & Stanje i održavanje & $\begin{array}{l}\text { po planu } \\
\text { održavanja }\end{array}$ & 1 & \\
\hline \multirow{3}{*}{ 7) Mikroklima } & $\begin{array}{l}\text { Temperatura } \\
\text { prostorije }\end{array}$ & $18-22^{0} \mathrm{C}$ & / & \\
\hline & $\begin{array}{l}\text { Relativ. vlažnost } \\
\text { prostori. }\end{array}$ & $65-80 \%$ & / & \\
\hline & $\begin{array}{l}\text { Brzina strujanja } \\
\text { vazduha }\end{array}$ & $\begin{array}{l}0,3 \mathrm{~m} / \mathrm{s} \\
\text { (klimatizovano) }\end{array}$ & / & \\
\hline \multirow[t]{2}{*}{ 8) Osvetljenje } & Opšta rasveta & $\begin{array}{l}\text { klasična propis. } \\
\text { izvedena }\end{array}$ & / & \\
\hline & Lokalna rasveta & ne zahteva se & 1 & \\
\hline \multirow{3}{*}{ 9) Ostalo } & Sanitarne prostorije & propis. izvedene & 1 & \\
\hline & Garderobe & ne zahteva se & 1 & \\
\hline & Ormarić za prvu pomoć & $\begin{array}{l}\text { propisana oprema } \\
\text { i postoji }\end{array}$ & / & \\
\hline $\begin{array}{l}\text { 3.4. Pomoćni radni } \\
\text { prostor: }\end{array}$ & \multicolumn{4}{|c|}{1} \\
\hline 3.5. Napomena: & \multicolumn{4}{|c|}{ Rad se izvodi na otvorenom prostoru } \\
\hline
\end{tabular}




\begin{tabular}{|l|l|}
\hline 4. RASPOLOŽIVA SREDSTVA I OPREMA ZA RAD \\
\hline 4.1. Mašine & $\begin{array}{l}\text { Mašine za geološka bušenja CHRISTENSEN CS 14; } \\
\text { CHRISTENSEN CS 10; } \\
\text { CHRISTENSEN CS 14 - CE C 20; }\end{array}$ \\
\hline 4.2. Uređaji & Kompresori, pumpe i dr. \\
\hline 4.3. Postrojenja & $/$ \\
\hline 4.4. Instalacije & Komprimirani vazduh \\
\hline 4.5. Alat i pribor & $\begin{array}{l}\text { Različite vrste alata za pritezanje cevi koje se koriste za geološka } \\
\text { bušenja }\end{array}$ \\
\hline 4.6. Druga sredstva za rad & Kombinovani putničko - teretni automobil \\
\hline
\end{tabular}

$\begin{aligned} & \text { 5. MATERIJALI, SIROVINE I DRUGE SUPSTANCE KOJE SE KORISTE U } \\
& \text { PROCESU RADA }\end{aligned}$
\begin{tabular}{|l|l|} 
5.1. Materijali & $\begin{array}{l}\text { Različite vrste repromaterijala kao što su: ulja i maziva; AMC } \\
\text { CR650 RD }\end{array}$ \\
\hline 5.2. Sirovine & $\begin{array}{l}\text { Uzorci mineralnih sirovina koji se dobijaju pri geološkom } \\
\text { bušenju }\end{array}$ \\
\hline 5.3. Druge supstance & $/$ \\
\hline
\end{tabular}

\begin{tabular}{|l|l|}
\hline \multicolumn{2}{|l|}{ 6. OSPOSOBLJAVANJE I OBUKE } \\
\hline 6.1. Specifično stručno osposobljavanje: & Da, obuka za rukovanje mašinom \\
\hline 6.2. Obuka za zaštitu zdravlja i bezbednost na radu: & Da, obuka je izvršena \\
\hline 6.3. Obuka za zaštitu od požara: & Da, obuka je izvršena \\
\hline
\end{tabular}

\begin{tabular}{|l|l|l|}
\hline \multicolumn{2}{|l|}{ 7. OPREMA I SREDSTVA ZA LIČNU ZAŠTITU NA RADU } & Ocena stanja \\
\hline 7.1. Sredstva za zaštitu glave: & Zastitni šlem & Zadovoljava \\
\hline 7.2. Sredstva za zaštitu tela: & Zaštitno odelo; Zaštni identifikacioni prsluk & Zadovoljava \\
\hline 7.3. Sredstva za zaštitu ruku: & Zaštitne rukavice & Zadovoljava \\
\hline 7.4. Sredstva za zaštitu nogu: & $\begin{array}{l}\text { Zaštitne cipele sa čeličnom kapnom; } \\
\text { Zaštitne gumene čizme sa čelič.kap. }\end{array}$ & Zadovoljava \\
\hline 7.5. Sredstava za zaštitu očiju: & Zaštitne naočare & Zadovoljava \\
\hline 7.6.Sredstava za zašt. sluha: & Zaštitni antifoni; Čepići za uši i dr. & Zadovoljava \\
\hline 7.7. Oprema za bezbedan rad: & Sigurnosni pojas za rad na visini & Zadovoljava \\
\hline
\end{tabular}

\begin{tabular}{|c|c|c|c|}
\hline \multicolumn{4}{|c|}{ 8. ORGANIZACIJA RADA } \\
\hline \multicolumn{4}{|c|}{ 8.1. Uslovi za zasnivanje radnog odnosa: } \\
\hline Stepen stručne spreme & \multicolumn{3}{|l|}{ Od II do VI } \\
\hline Obrazovni profil & \multicolumn{3}{|l|}{ Svih struka } \\
\hline Radno iskustvo & \multicolumn{3}{|l|}{ Poželjno je } \\
\hline $\begin{array}{l}\text { Posebno znanje, veštine i } \\
\text { sposobnost }\end{array}$ & \multicolumn{3}{|c|}{ Sposobnost upravlanja motornim vozilom } \\
\hline \multicolumn{4}{|c|}{ 8.2. Opšti podaci o izvršiocima: } \\
\hline $\begin{array}{l}\text { Ukupan broj zaposlenih na } \\
\text { radnom mestu/grupi: }\end{array}$ & $>4$ & Muškarci: da & Žene: ne \\
\hline $\begin{array}{l}\text { Na radnom mestu rade } \\
\text { invalidi rada: }\end{array}$ & $\mathrm{Ne}$ & Muškarci:/ & Zene: / \\
\hline
\end{tabular}




\begin{tabular}{|l|l|l|l|}
\hline 8.3. Opšti zahtevi radnog mesta: \\
\hline \multirow{4}{*}{$\begin{array}{l}\text { Angažovanje prema } \\
\text { mestu aktivnosti }\end{array}$} & $\begin{array}{l}\text { U radnim } \\
\text { prostorijama }\end{array}$ & Kancelarija & $0 \%$ \\
\cline { 2 - 4 } & $\begin{array}{l}\text { Rad na } \\
\text { otvorenom }\end{array}$ & Pom. radne prostorije & $0 \%$ \\
\cline { 2 - 4 } & Radi u smenama & Radilište & $100 \%$ \\
\cline { 2 - 4 } & Rad sa prevoznim sredstvom & Da, povremeno \\
\hline \multirow{4}{*}{ Izvršavanje zadataka } & Radi noću & Da & \\
\cline { 2 - 4 } & $\begin{array}{l}\text { Organizuje i } \\
\text { rukovodi }\end{array}$ & Da & \\
\hline
\end{tabular}

\begin{tabular}{|l|c|c|}
\hline $\begin{array}{l}\text { 9. ANALIZA POSTOJEĆEG STANJA BEZBEDNOSTI I ZDRAVLJA NA } \\
\text { RADNOM MESTU }\end{array}$ & $\begin{array}{c}\text { 9.2. Usklađenost sa } \\
\text { zahtevima }\end{array}$ \\
\hline & Da $\checkmark$ & Ne x \\
\hline \multirow{2}{*}{ 9.1. Element bezbednosti na radu } & $\checkmark$ & \\
\hline $\begin{array}{l}\text { Važeći stručni nalazi o izvršenim pregledima i ispitivanjima sredstava za } \\
\text { rad }\end{array}$ & $\checkmark$ & \\
\hline Važeći stručni nalazi o izvršenim pregledima i ispitivanjima uslova rada & $\checkmark$ & \\
\hline Izveštaji o prethodnim i periodičnim lekarskim pregledima zaposlenih & $\checkmark$ & \\
\hline Podaci o povredama na radu & $\checkmark$ & \\
\hline Podaci o profesionalnim bolestima i oboljenjima u vezi sa radom & $\checkmark$ & \\
\hline Sredstva i oprema za ličnu zaštitu na radu & $\checkmark$ & \\
\hline Analiza preduzetih mera radi sprečavanja povreda na radu & $\checkmark$ & \\
\hline Uputstva za bezbedan rad & $\checkmark$ & \\
\hline $\begin{array}{l}\text { Propisana dokumentacija za upotrebu i održavanje, odnosno pakovanje, } \\
\text { transport, koriščenje, skladištenje, uništavanje i dr. }\end{array}$ & $\checkmark$ & \\
\hline Zaštita od požara & & \\
\hline
\end{tabular}

\begin{tabular}{|c|c|c|c|c|}
\hline \multicolumn{5}{|c|}{ 10. PREPOZNAVANJE OPASNOSTI NA RADNOM MESTU } \\
\hline \multicolumn{5}{|c|}{ 10.1. Grupisanje opasnosti } \\
\hline Grupa opasnosti & \multirow{2}{*}{$\begin{array}{r}\text { Šifra } \\
(01)\end{array}$} & \multirow{2}{*}{\begin{tabular}{l}
\multicolumn{1}{c}{ Podgupa opasnosti } \\
$\begin{array}{l}\text { Nedovoljna bezbednost zbog rotirajućih ili } \\
\text { pokretnih delova, }\end{array}$
\end{tabular}} & \multicolumn{2}{|c|}{$\begin{array}{c}\text { Opasnosti } \\
\checkmark \text { IMA / } \times \text { NEMA }\end{array}$} \\
\hline \multirow{6}{*}{$\begin{array}{l}\text { 1) Mehaničke } \\
\text { opasnosti koje } \\
\text { se pojavljuju } \\
\text { korišćenjem } \\
\text { opreme za } \\
\text { rad kao što } \\
\text { su: }\end{array}$} & & & $\checkmark$ & \\
\hline & $(02)$ & $\begin{array}{l}\text { Slobodno kretanje delova ili materijala koji } \\
\text { mogu naneti povredu zaposlenom, }\end{array}$ & $\checkmark$ & \\
\hline & $(03)$ & $\begin{array}{l}\text { Unutrašnji transport i kretanje radnih mašina } \\
\text { ili vozila, kao i pomeranja određene opreme } \\
\text { za rad, }\end{array}$ & $\checkmark$ & \\
\hline & $(04)$ & $\begin{array}{l}\text { Korišćenje opasnih sredstava za rad, koja } \\
\text { mogu proizvesti eksplozije ili požar, }\end{array}$ & $\checkmark$ & \\
\hline & $(05)$ & $\begin{array}{l}\text { Nemogućnost ili ograničenost pravovremenog } \\
\text { uklanjanja sa mesta rada, izloženost zatvaranju, } \\
\text { mehaničkom udaru, poklapanju, i sl., }\end{array}$ & $\checkmark$ & \\
\hline & $(06)$ & $\begin{array}{l}\text { Drugi faktori koji mogu da se pojave kao } \\
\text { mehanički izvori opasnosti. }\end{array}$ & $\checkmark$ & \\
\hline
\end{tabular}




\begin{tabular}{|c|c|c|c|c|}
\hline \multirow{8}{*}{$\begin{array}{l}\text { 2) Opasnosti koje } \\
\text { se pojavljuju u } \\
\text { vezi sa karakte- } \\
\text { ristikama } \\
\text { radnog mesta } \\
\text { kao što su: }\end{array}$} & $(07)$ & $\begin{array}{l}\text { Opasne površine (podovi i sve vrste gazišta, } \\
\text { površine sa kojima zaposleni dolazi u dodir, a koje } \\
\text { imaju oštre ivice-rubove, šiljke, grube površine, } \\
\text { izbočene delove, i sl.) }\end{array}$ & $\checkmark$ & \\
\hline & $(08)$ & $\begin{array}{l}\text { Rad na visini ili u dubini, u smislu propisa o } \\
\text { bezbednosti i zdravlju na radu, }\end{array}$ & $\checkmark$ & \\
\hline & $(09)$ & $\begin{array}{l}\text { Rad u skučenom, ograničenom ili opasnom prostoru } \\
\text { (između dva ili više fiksiranih delova, između pokretnih } \\
\text { delova ili vozila, rad u zatvorenom prostoru koji je } \\
\text { nedovoljno osvetljen ili provetravan, i sl.), }\end{array}$ & & $x$ \\
\hline & $(10)$ & $\begin{array}{l}\text { Mogućnost klizanja ili spoticanja (mokre ili klizave } \\
\text { površine), }\end{array}$ & $\checkmark$ & \\
\hline & $(11)$ & Fizička nestabilnost radnog mesta, & & $x$ \\
\hline & $(12)$ & $\begin{array}{l}\text { Moguće posledice ili smetnje usled obavezne upotrebe } \\
\text { sredstava ili opreme za ličnu zaštitu na radu, }\end{array}$ & $\checkmark$ & \\
\hline & (13) & $\begin{array}{l}\text { Uticaji usled obavljanja procesa rada korišćenjem } \\
\text { neodgovarajućih ili neprilagođenih metoda rada, }\end{array}$ & & $\mathbf{x}$ \\
\hline & (14) & $\begin{array}{l}\text { Druge opasnosti koje se mogu pojaviti u vezi sa } \\
\text { karakteristikama radnog mesta i načinom rada } \\
\text { (korišćenje sredstava i opreme za ličnu zaštitu na } \\
\text { radu koja opterećuju zaposlenog, i sl.); }\end{array}$ & $\checkmark$ & \\
\hline \multirow{6}{*}{$\begin{array}{l}\text { 3) Opasnosti koje } \\
\text { se pojavljuju } \\
\text { korišćenjem } \\
\text { električne } \\
\text { energije, } \\
\text { kao što su: }\end{array}$} & $(15)$ & $\begin{array}{l}\text { Opasnost od direktnog dodira sa delovima } \\
\text { električne instalacije i opreme pod naponom, }\end{array}$ & & $x$ \\
\hline & $(16)$ & Opasnost od indirektnog dodira, & & $x$ \\
\hline & (17) & $\begin{array}{l}\text { Opasnost od toplotnog dejstva koje razvijaju električna } \\
\text { oprema i instalacije (pregrevanje, požar, eksplozija, } \\
\text { električni luk ili varničenje, i dr), }\end{array}$ & & $x$ \\
\hline & $(18)$ & $\begin{array}{l}\text { Opasnosti usled udara groma i posledica atmosferskog } \\
\text { pražnjenja }\end{array}$ & $\checkmark$ & $x$ \\
\hline & (19) & $\begin{array}{l}\text { Opasnost od štetnog uticaja elektrostatičkog } \\
\text { naelektrisanja, }\end{array}$ & & $x$ \\
\hline & $(20)$ & $\begin{array}{l}\text { Druge opasnosti koje se mogu pojaviti u vezi sa } \\
\text { korišćenjem električne energije. }\end{array}$ & & $x$ \\
\hline
\end{tabular}

\begin{tabular}{|c|c|c|c|c|}
\hline \multicolumn{5}{|c|}{ 11. PREPOZNAVANJE ŠTETNOSTI NA RADNOM MESTU } \\
\hline \multicolumn{5}{|c|}{ 11.1.Grupisanje štetnosti } \\
\hline Grupa štetnosti & Šifra & Podgupa štetnosti & \multicolumn{2}{|c|}{$\begin{array}{c}\text { Štetnosti } \\
\checkmark \text { IMA / } \times \text { NEMA }\end{array}$} \\
\hline \multirow{9}{*}{$\begin{array}{l}\text { 1) Štetnosti koje } \\
\text { nastaju ili se } \\
\text { pojavljuju u } \\
\text { procesu rada, } \\
\text { kao što su: }\end{array}$} & $(21)$ & $\begin{array}{l}\text { Hemijske štetnosti, prašina i dimovi (udisanje, } \\
\text { gušenje, unošenje u organizam, prodor u telo kroz } \\
\text { kožu, opekotine, trovanje, i sl.), }\end{array}$ & $\checkmark$ & \\
\hline & $(22)$ & Fizičke štetnosti (buka i vibracije), & $\checkmark$ & \\
\hline & $(23)$ & $\begin{array}{l}\text { Biološke štetnosti (infekcije, izlaganje mikroorga- } \\
\text { nizmima i alergenima), }\end{array}$ & & $x$ \\
\hline & (24) & $\begin{array}{l}\text { Štetni uticaji mlkroklime (visoka ili niska } \\
\text { temperatura, vlažnost i brzina strujanja vazduha), }\end{array}$ & & $x$ \\
\hline & $(25)$ & Neodgovarajuća - nedovoljna osvetljenost, & $\checkmark$ & \\
\hline & $(26)$ & $\begin{array}{l}\text { Stetni uticaji zračenja (toplotnog, jonizujućeg ili } \\
\text { nejonizujućeg, laserskog, ultrazvučnog), }\end{array}$ & & $x$ \\
\hline & $(27)$ & Štetni klimatski uticaji (rad na otvorenom), & $\checkmark$ & \\
\hline & $(28)$ & $\begin{array}{l}\text { Štetnosti koje nastaju korišćenjem opasnih materija } \\
\text { u proizvodnji, transportu, pakovanju, skladištenju } \\
\text { ili uništavanju, }\end{array}$ & & $x$ \\
\hline & $(29)$ & $\begin{array}{l}\text { Druge štetnosti koje se pojavljuju u radnom procesu, a } \\
\text { koje mogu da budu uzrok povrede na radu zapo- } \\
\text { slenog, profesionalnog oboljenja ili oboljenja u vezi sa } \\
\text { radom. }\end{array}$ & $\checkmark$ & \\
\hline
\end{tabular}




\begin{tabular}{|c|c|c|c|c|}
\hline \multirow{4}{*}{$\begin{array}{l}\text { 2) Štetnosti koje } \\
\text { proističu iz } \\
\text { psihičkih i } \\
\text { psihofiziološki } \\
\text { h napora koji } \\
\text { se uzročno } \\
\text { vezuju za } \\
\text { radno mesto i } \\
\text { poslove koje } \\
\text { zaposleni } \\
\text { obavlja, } \\
\text { kao što su: }\end{array}$} & $(30)$ & $\begin{array}{l}\text { Napori ili telesna naprezanja (ručno prenošenje } \\
\text { tereta, guranje ili vučenje tereta, razne dugotrajne } \\
\text { povećane telesne aktivnosti i sl.), }\end{array}$ & $\checkmark$ & \\
\hline & $(31)$ & $\begin{array}{l}\text { Nefiziološki položaj tela (dugotrajno stajanje, } \\
\text { sedenje, čučanje, klečanje i sl.), }\end{array}$ & $\checkmark$ & \\
\hline & $(32)$ & $\begin{array}{l}\text { Napori pri obavljanju određenih poslova koji } \\
\text { prouzrokuju psihološka opterećenja (stres, } \\
\text { monotonija i sl.), }\end{array}$ & $\checkmark$ & \\
\hline & $(33)$ & $\begin{array}{l}\text { Odgovornost u primanju i prenošenju informacija, } \\
\text { korišćenje odgovarajućeg znanja i sposobnosti, } \\
\text { odgovornost u pravilima ponašanja, odgovornost za } \\
\text { brze izmene radnih procedura, intenzitet u radu, } \\
\text { prostorna uslovljenost radnog mesta, konfliktne } \\
\text { situacije, rad sa strankama i novcem, nedovoljna } \\
\text { motivacija za rad, odgovornost u rukovođenju, i sl.; }\end{array}$ & $\checkmark$ & \\
\hline $\begin{array}{l}\text { 3) Štetnosti } \\
\text { vezane za } \\
\text { organizaciju } \\
\text { rada, kao štosu: }\end{array}$ & (34) & $\begin{array}{l}\text { Rad duži od punog radnog vremena (prekovremeni } \\
\text { rad), rad u smenama, skraćeno radno vreme, rad noću, } \\
\text { pripravnost za slučaj intervencija, }\end{array}$ & $\checkmark$ & \\
\hline \multirow{5}{*}{$\begin{array}{l}\text { 4) Ostale štetnosti } \\
\text { koje se } \\
\text { pojavljuju na } \\
\text { radnim } \\
\text { mestima, } \\
\text { kao što su: }\end{array}$} & $(35)$ & $\begin{array}{l}\text { Štetnosti koje prouzrokuju druga lica (nasilje prema } \\
\text { licima koja rade na šalterima, lica na obezbeđenju, i } \\
\text { sl.), }\end{array}$ & & $x$ \\
\hline & $(36)$ & Rad sa životinjama, & & $x$ \\
\hline & $(37)$ & Rad u atmosferi sa visokim ili niskim pritiskom, & & $x$ \\
\hline & $(38)$ & Rad u blizini vode ili ispod površine vode, & & $x$ \\
\hline & (39) & Ostale opasnosti i štetnosti. & & $x$ \\
\hline
\end{tabular}

\section{UTVRĐIVANJE LISTE OPASNOSTI I ŠTETNOSTI NA RADNOM MESTU}

\subsection{Utvrđena lista opasnosti}

01.1 Opasnost od povreda na radu uzrokovana od rotirajućih ili pokretnih delova na mašini za geološka bušenja i istraživanja

02.1 Opasnost od povreda na radu uzrokovana od kretanja delova pri izvođenju geoloških bušenja i istraživanja

03.1 Opasnost od povreda na radu uzrokovana od kretanja radnih mašina i vozila kao i opreme koja se koristi pri geološkim bušenjima i istraživanjima

04.1 Opasnost od povreda na radu uzrokovana od korišćenje kompresora i dizel agregata koji proizvode velike pritiske i koji mogu uzrokovati eksplozije i požare

05.1 Opasnost od povreda na radu uzrokovana od nemogućnost ili ograničenost pravovremenog uklanjanja sa mesta rada na mašini za geološka bušenja i istrživanja

06.1 Opasnost od povreda na radu uzrokovana od potencijalnih saobraćajnih udesa pri povremenom upravljanju putničkim ili poluteretnim vozilom na kategorisanim i nekategorisanim putevima i prevozu radnog osoblja od baze do mesta rada i obratno;

07.1 Opasnost od povreda na radu uzrokovana od vrsta gazišta i rubova, grubih površina i izbočenih delova koji se nalaze na mašinama za geološka bušenja i istraživanja;

08.1 Opasnost od povreda na radu uzrokovana radom na visini pri opsluživanju i održavanju mašina za geološka bušenja i istraživanja 


\begin{tabular}{|c|c|}
\hline 10.1 & $\begin{array}{l}\text { Opasnost od povreda na radu uzrokovana mogućnost klizanja ili spoticanja (mokre } \\
\text { ili klizave površine) na mašinama i/ili na istražnom prostoru na kome se vrše } \\
\text { geološka bušenja. }\end{array}$ \\
\hline 12.1 & $\begin{array}{l}\text { Opasnost od povreda na radu uzrokovana od usled obavezne upotrebe sredstava ili } \\
\text { opreme za ličnu zaštitu na radu (antifoni; naočare; rukavice i sl.) }\end{array}$ \\
\hline 14.1 & $\begin{array}{l}\text { Opasnost od povreda na radu uzrokovana otežanom preciznošću rada i otežanom } \\
\text { kretanju usled obaveznog korišćenja opreme za ličnu zaštitu na radu. }\end{array}$ \\
\hline 18.1 & $\begin{array}{l}\text { Opasnost od povreda na radu uzrokovana od prirodnih nepogoda i udara groma i } \\
\text { posledica atmosferskog pražnjenja. }\end{array}$ \\
\hline \multicolumn{2}{|r|}{ 12.2. Utvrđena lista štetnosti } \\
\hline 21.1 & $\begin{array}{l}\text { Štetnost po zdravlje uzrokovan hemijskim štetnostima uzrokovana radom dizel } \\
\text { agregata, radom sa isplakama koje sadrže hemijske supstance i prašina koje se } \\
\text { javljaju pri geološkim bušenjima. }\end{array}$ \\
\hline 22.1 & $\begin{array}{l}\text { Štetnost po zdravlje uzrokovana bukom od rada dizel agregata i mašina za geološka } \\
\text { bušenja i istraživanja. }\end{array}$ \\
\hline 25.1 & Štetnost po zdravlje uzrokovana nedovoljnom osvetljenošću u toku noćnog rada \\
\hline 27.1 & $\begin{array}{l}\text { Štetnost po zdravlje uzrokovana štetnim klimatskim uticajima pri radu otvorenom } \\
\text { prostoru u toku geoloških bušenja i istraživanja. }\end{array}$ \\
\hline 29.1 & $\begin{array}{l}\text { Štetnost po zdravlje uzrokovana štetnostima koje nastaju korišćenjem ulja, maziva, } \\
\text { dizel goriva i sl. }\end{array}$ \\
\hline 30.1 & $\begin{array}{l}\text { Štetnost po zdravlje uzrokovana naporima i telesnim naprezanjima pri ručnom } \\
\text { prenošenju cevi, alata i pribora za geološka bušenja. }\end{array}$ \\
\hline 31.1 & $\begin{array}{l}\text { Štetnost po zdravlje uzrokovana nefiziološkim položajem tela pri dugotrajnom stajanju, } \\
\text { čučanju ili klečanju pri nadzoru i opsluživanju mašina za geološka bušenja i } \\
\text { istraživanja. }\end{array}$ \\
\hline 32.1 & $\begin{array}{l}\text { Štetnost po zdravlje uzrokovana naporima psihofizičkih opterećenja u nadgledanju i } \\
\text { kontoli rada mašina za geološka bušenja i istraživanje. }\end{array}$ \\
\hline 33.1 & $\begin{array}{l}\text { Štetnost po zdravlje uzrokovana odgovornošću u primanju i prenošenju informacija, } \\
\text { korišćenju odgovarajućeg znanja i sposobnosti za rad na mašinama za geološka bušenja } \\
\text { i istraživanja. }\end{array}$ \\
\hline 34.1 & $\begin{array}{l}\text { Štetnost po zdravlje uzrokovana produženim radom kao i radom noću pri geološkim } \\
\text { bušenjima i istraživanjima. }\end{array}$ \\
\hline
\end{tabular}

\begin{tabular}{|c|c|c|c|c|c|c|}
\hline 13. PROCENA OH\&S RIZIKA \\
\hline $\mathbf{1 3 . 1}$ & $\begin{array}{c}\text { Procena rizika za tvrdene } \\
\text { konkretne opasnosti }\end{array}$ & V & T & U & R-Rizik & Mere kon. pro.riz. \\
\hline 01.1 & $\begin{array}{l}\text { Opasnost od povreda na radu uzroko- } \\
\text { vana od rotirajući ili pokretnih } \\
\text { delova na mašini za geološka bušenja } \\
\text { i istraživanja. }\end{array}$ & 6 & 3 & 6 & 108 & $\begin{array}{l}\text { Uputstvo za bezbedan rad } \\
\text { pri geološkim bušenjima. }\end{array}$ \\
\hline 02.1 & $\begin{array}{l}\text { Opasnost od povreda na radu uzro- } \\
\text { kovana od kretanja delova pri izvo- } \\
\text { đenju geoloških bušenja i istraživanja. }\end{array}$ & 6 & 3 & 6 & 108 & $\begin{array}{l}\text { Primena tehničkih zaštitnih } \\
\text { naprava. } \\
\text { Uputstvo za bezbedan rad } \\
\text { pri geološkim bušenjima. }\end{array}$ \\
\hline
\end{tabular}




\begin{tabular}{|c|c|c|c|c|c|c|}
\hline 03.1 & $\begin{array}{l}\text { Opasnost od povreda na radu uzro- } \\
\text { kovana od kretanja radnih mašina i } \\
\text { vozila kao i opreme koja se koristi pri } \\
\text { geološkim bušenjima i istraživanjima. }\end{array}$ & 3 & 3 & 6 & 54 & $\begin{array}{l}\text { Uputstvo za bezbedan rad } \\
\text { pri geološkim bušenjima; } \\
\text { Uputstvo - mere } \\
\text { bezbednosti na radilištu. }\end{array}$ \\
\hline 04.1 & $\begin{array}{l}\text { Opasnost od povreda na radu } \\
\text { uzrokovana od korišćenje kompresora } \\
\text { i dizel agregata koji proizvode velike } \\
\text { pritiske i koji mogu uzrokovati } \\
\text { eksplozije i požare. }\end{array}$ & 3 & 3 & 6 & 54 & $\begin{array}{l}\text { Uputstvo za bezbedan rad } \\
\text { na mašinama }\end{array}$ \\
\hline 05.1 & $\begin{array}{l}\text { Opasnost od povreda na radu } \\
\text { uzrokovana od nemogućnost ili } \\
\text { ograničenost pravovremenog ukla- } \\
\text { njanja sa mesta rada na mašini za } \\
\text { geološka bušenja i istrživanja. }\end{array}$ & 6 & 3 & 6 & 108 & $\begin{array}{l}\text { Uputstvo za bezbedan rad } \\
\text { na mašinama }\end{array}$ \\
\hline 06.1 & $\begin{array}{l}\text { Opasnost od povreda na radu uzro- } \\
\text { kovana od potencijalnih saobraćajnih } \\
\text { udesa pri povremenom upravljanju } \\
\text { putničkim ili poluteretnim vozilom na } \\
\text { kategorisanim i nekategorisanim } \\
\text { putevima i prevozu radnog osoblja od } \\
\text { baze do mesta rada i obratno. }\end{array}$ & 6 & 3 & 6 & 108 & $\begin{array}{l}\text { Mere zaštite pri upotrebi } \\
\text { motornih vozila }\end{array}$ \\
\hline 07.1 & $\begin{array}{l}\text { Opasnost od povreda na radu } \\
\text { uzrokovana od vrsta gazišta i rubova, } \\
\text { grubih površina i izbočenih delova } \\
\text { koji se nalaze na mašinama za } \\
\text { geološka bušenja i istraživanja. }\end{array}$ & 3 & 3 & 6 & 54 & $\begin{array}{l}\text { Opšte uputstvo za } \\
\text { bezbedan rad; Uputstvo - } \\
\text { mere bezbednosti na } \\
\text { radilištu }\end{array}$ \\
\hline 08.1 & $\begin{array}{l}\text { Opasnost od povreda na radu } \\
\text { uzrokovana radom na visini pri } \\
\text { opsluživanju i održavanju mašina za } \\
\text { geološka bušenja i istraživanja. }\end{array}$ & 6 & 3 & 6 & 108 & $\begin{array}{l}\text { Uputstvo za bezbedan rad } \\
\text { na visini }\end{array}$ \\
\hline 10.1 & $\begin{array}{l}\text { Opasnost od povreda na radu uzro- } \\
\text { kovana mogućnost klizanja ili spoti- } \\
\text { canja (mokre ili klizave površine) na } \\
\text { mašinama i/ili na istražnom prostoru } \\
\text { na kome se vrše geološka bušenja. }\end{array}$ & 3 & 3 & 6 & 54 & $\begin{array}{l}\text { Uputstvo - mere } \\
\text { bezbednosti na radilištu; } \\
\text { Mere zaštite od klizanja, } \\
\text { saplitanja i padanja }\end{array}$ \\
\hline 12.1 & $\begin{array}{l}\text { Opasnost od povreda na radu } \\
\text { uzrokovana usled obavezne upotrebe } \\
\text { sredstava ili opreme za ličnu zaštitu na } \\
\text { radu (antifoni; naočare; rukavice i sl.). }\end{array}$ & 3 & 3 & 6 & 54 & $\begin{array}{l}\text { Mere zaštite pri upotrebi } \\
\text { LZS }\end{array}$ \\
\hline 14.1 & $\begin{array}{l}\text { Opasnost od povreda na radu } \\
\text { uzrokovana otežanom preciznošću } \\
\text { rada i otežanom kretanju usled } \\
\text { obaveznog korišćenja opreme za ličnu } \\
\text { zaštitu na radu. }\end{array}$ & 3 & 3 & 6 & 54 & $\begin{array}{l}\text { Mere zaštite pri upotrebi } \\
\text { LZS }\end{array}$ \\
\hline 18.1 & $\begin{array}{l}\text { Opasnost od povreda na radu } \\
\text { uzrokovana od prirodnih nepogoda } \mathrm{i} \\
\text { udara groma i posledica atmosferskog } \\
\text { pražnjenja. }\end{array}$ & 1 & 3 & 1 & 3 & $\begin{array}{l}\text { Uputstvo za rad pri } \\
\text { geološkim bušenjima }\end{array}$ \\
\hline 13.2 & $\begin{array}{l}\text { Procena rizik za tvrđene konkretne } \\
\text { štetnosti }\end{array}$ & $\mathbf{V}$ & $\mathbf{T}$ & $\mathbf{U}$ & R-Rizik & Mere kon. pro.riz. \\
\hline
\end{tabular}




\begin{tabular}{|c|c|c|c|c|c|c|}
\hline 21.1 & $\begin{array}{l}\text { Štetnost po zdravlje uzrokovan hemij- } \\
\text { skim štetnostima uzrokovana radom } \\
\text { dizel agregata, radom sa isplakama } \\
\text { koje sadrže hemijske supstance i } \\
\text { prašina koje se javljaju pri geološkim } \\
\text { bušenjima. }\end{array}$ & 6 & 3 & 6 & 108 & $\begin{array}{l}\text { Primena ličnih zaštitnih } \\
\text { sredstava }\end{array}$ \\
\hline 22.1 & $\begin{array}{l}\text { Štetnost po zdravlje uzrokovana } \\
\text { bukom od rada dizel agregata i mašina } \\
\text { za geološka bušenja i istraživanja. }\end{array}$ & 6 & 3 & 6 & 108 & $\begin{array}{l}\text { Primena ličnih zaštitnih } \\
\text { sredstava }\end{array}$ \\
\hline 25.1 & $\begin{array}{l}\text { Štetnost po zdravlje uzrokovana } \\
\text { nedovoljnom osvetljenošću u toku } \\
\text { noćnog rada. }\end{array}$ & 3 & 3 & 6 & 54 & $\begin{array}{l}\text { Uputstvo - mere bezbed. } \\
\text { na radilišstu }\end{array}$ \\
\hline 27.1 & $\begin{array}{l}\text { Štetnost po zdravlje uzrokovana } \\
\text { štetnim klimatskim uticajima pri radu } \\
\text { otvorenom prostoru u toku geoloških } \\
\text { bušenja i istraživanja. }\end{array}$ & 6 & 3 & 6 & 108 & $\begin{array}{l}\text { Primena ličnih zaštitnih } \\
\text { sredstava }\end{array}$ \\
\hline 29.1 & $\begin{array}{l}\text { Štetnost po zdravlje uzrokovana } \\
\text { štetnostima koje nastaju korišćenjem } \\
\text { ulja, maziva, dizel goriva i sl. }\end{array}$ & 6 & 3 & 6 & 108 & $\begin{array}{l}\text { Primena ličnih zaštitnih } \\
\text { sredstava }\end{array}$ \\
\hline 30.1 & $\begin{array}{l}\text { Štetnost po zdravlje uzrokovana } \\
\text { naporima i telesnim naprezanjima pri } \\
\text { ručnom prenošenju cevi, alata i } \\
\text { pribora za geološka bušenja. }\end{array}$ & 6 & 3 & 6 & 108 & $\begin{array}{l}\text { Primena ličnih zaštitnih } \\
\text { sredstava }\end{array}$ \\
\hline 31.1 & $\begin{array}{l}\text { Štetnost po zdravlje uzrokovana } \\
\text { nefiziološkim položajem tela pri } \\
\text { dugotrajnom stajanju, čučanju } \\
\text { klečanju pri nadzoru i } \\
\text { mašina za opsluživanju } \\
\text { istraživanja. }\end{array}$ & 6 & 3 & 6 & 108 & $\begin{array}{l}\text { Primena ličnih zaštitnih } \\
\text { sredstava }\end{array}$ \\
\hline 32.1 & $\begin{array}{l}\text { Štetnost po zdravlje uzrokovana } \\
\text { naporima psihofizičkih opterećenja u } \\
\text { nadgledanju i kontoli rada mašina za } \\
\text { geološka bušenja i istraživanje. }\end{array}$ & 3 & 2 & 6 & 36 & $\begin{array}{l}\text { Propisno koristiti propisane } \\
\text { pauze u radu (dnevne, } \\
\text { nedeljne, godišnje) }\end{array}$ \\
\hline 33.1 & $\begin{array}{l}\text { Štetnost po zdravlje uzrokovana } \\
\text { odgovornošću u primanju i prenošenju } \\
\text { informacija, korišćenju odgovarajućeg } \\
\text { znanja i sposobnosti za rad na } \\
\text { mašinama za geološka bušenja i } \\
\text { istraživanja. }\end{array}$ & 3 & 2 & 6 & 36 & $\begin{array}{l}\text { Propisno koristiti propisane } \\
\text { pauze u radu (dnevne, } \\
\text { nedeljne, godišnje) }\end{array}$ \\
\hline 34.1 & $\begin{array}{l}\text { Štetnost po zdravlje uzrokovana } \\
\text { produženim radom kao i radom noću } \\
\text { pri geološkim bušenjima i istraži- } \\
\text { vanjima. }\end{array}$ & 3 & 2 & 6 & 36 & $\begin{array}{l}\text { Propisno koristiti propisane } \\
\text { pauze u radu (dnevne) }\end{array}$ \\
\hline \multicolumn{7}{|c|}{ 13.3. Komentar procenjenih opasnosti i štetnosti: } \\
\hline \multicolumn{7}{|c|}{$\begin{array}{l}\text { Na osnovu identifikovanih, analiziranih i utvrđenih konkretnih opasnosti i štetnosti na radnom mestu i } \\
\text { radnoj okolini Bušač-Geološka istražna bušenja, procenjene verovatnoće nastanka povreda na radu, } \\
\text { oštećenja zdravlja i oboljenja u vezi sa radom i procene težine povrede na radu, oštećenja zdravlja i } \\
\text { oboljenja u vezi sa, procenjen je SREDNJI RIZIK (R III) od povreda na radu, oštećenja zdravlja i } \\
\text { oboljenja u vezi sa radom. }\end{array}$} \\
\hline
\end{tabular}




\subsection{Mišljenje službe medicine rada:}

Stručni tim medicine rada sagledao je procenjene opasnosti i štetnosti zaradno mesto BušačGeološka istražna bušenja i mišljenja je da postoje indikacije za proglašenje radnog mesta sa povećanim rizikom.

13.5. Konačan zaključakTima za procenu $O H \& S$ rizika:

$\mathrm{Na}$ osnovu procenjenih konkretnih opasnosti i štetnosti Tim za procenu $\mathrm{OH} \& \mathrm{~S}$ rizika donosi: KONAČAN ZAKLJUČAK

Za radno mesto Bušač-Geološka istražna bušenja utvđen je NIVO RIZIKA R III -

SREDNJI RIZIK od povreda na radu, oštećenja zdravlja i oboljenja u vezi sa radom.

Na osnovu konačnog zaključka o proceni OH\&S rizika navedeno radno mesto kategoriše se kao radno mesto sa POVEĆANIM RIZIKOM.

Za uspostavljanje mehanizama kontrole/upravljanja povećanim OH\&S rizicima neophodno je definisati PLAN UPRAVLJANJA PROCENJENIM OH\&S RIZICIMA.

\begin{tabular}{|c|c|c|c|c|c|c|c|}
\hline \multicolumn{8}{|c|}{ 14. PLAN UPRAVLJANJA PROCENJENIM OH\&S RIZICIMA } \\
\hline \multirow[b]{2}{*}{ Rizik } & \multirow{2}{*}{$\begin{array}{l}\text { Lista povećanih } \\
\text { OH\&S rizika za } \\
\text { radno mesto } \\
\text { Bušač-Geološka } \\
\text { istražna bušenja }\end{array}$} & \multicolumn{5}{|c|}{\begin{tabular}{|l} 
Hijerarhija upravljanja povećanim $\mathrm{OH} \& S$ rizicima \\
\end{tabular}} & \multirow[b]{2}{*}{ Prioritet } \\
\hline & & $\begin{array}{l}\text { 1. Mere } \\
\text { potpunog } \\
\text { otklanjanja } \\
\text { rizika: }\end{array}$ & $\begin{array}{l}\text { 2. Mere zamene } \\
\text { (substitucije) } \\
\text { rizika: }\end{array}$ & $\begin{array}{l}\text { 3. Mere tehničke } \\
\text { (inženjerske) } \\
\text { kontrole } \\
\text { rizika: }\end{array}$ & $\begin{array}{l}\text { 4. Mere signalizacije } \\
\text { upozorenja ili } \\
\text { administrativne } \\
\text { kontole rizika: }\end{array}$ & $\begin{array}{l}\text { 5. Mere primene } \\
\text { LZS i opreme } \\
\text { za BNR }\end{array}$ & \\
\hline \multirow[t]{4}{*}{108} & \multirow{4}{*}{$\begin{array}{l}\text { Opasnost od } \\
\text { povreda na radu } \\
\text { uzrokovana od } \\
\text { rotirajućih ili } \\
\text { pokretnih delova na } \\
\text { mašini za geološka } \\
\text { bušenja i istraživanja }\end{array}$} & $\begin{array}{l}\text { Nije } \\
\text { primenljivo }\end{array}$ & $\begin{array}{l}\text { Obavezna primena } \\
\text { tehničkih zaštitnih } \\
\text { naprava kod } \\
\text { rotirajućih i } \\
\text { pokretnih delova }\end{array}$ & $\begin{array}{l}\text { Obavezan dnevni } \\
\text { i nedeljni pregled } \\
\text { i periodično } \\
\text { ispitivanje }\end{array}$ & $\begin{array}{l}\text { Obavezna primena } \\
\text { procedura, uputstava. } \\
\text { Obavezna obuka za } \\
\text { bezbedan rad. } \\
\text { Obavezan periodični } \\
\text { lekarski pregled }\end{array}$ & $\begin{array}{l}\text { Obavezna } \\
\text { primena ličnih } \\
\text { zaštitnih } \\
\text { sredstava i } \\
\text { opreme za } \\
\text { bezbedan rad }\end{array}$ & Veliki \\
\hline & & & & & & & \\
\hline & & & & & & & \\
\hline & & & & & & & \\
\hline 108 & $x$ & & & & & & \\
\hline 54 & $y$ & & & & & & \\
\hline 36 & $z$ & & & & & & \\
\hline
\end{tabular}

\section{ZAKLJUČAK}

Institucionalne promene koje su se desile u Republici Srbiji u oblasti zaštite zdravlja i bezbednosti na radu neminovno su uslovile potrebu za razvojem i poboljšanjem alata za donošenje odluka pri planiranju, i upravljanju sistemom zaštite zdravlja i bezbednosti na radu. Donošenje odluka na osnovu prethodno prikazanog modela i metoda procene OH\&S rizika je fleksibilni pristup koji je proaktivan i obezbedjuje identifikaciju, određivanje prioriteta i dokumen- tovanost $\mathrm{OH} \& \mathrm{~S}$ rizika, kao i primenu Plana mera za kontrolu procenjenih $\mathrm{OH} \& \mathrm{~S}$ rizika.

$\mathrm{Na}$ osnovu detaljne identifikacije i analize opasnosti i štetnosti za radon mesto Bušač - Geološka istražna bušenja u organizaciji "Geops Balkan Driling Services" d.o.o, može se zaključiti da je optimizovana metoda Kinny i metodološki pristupak procene OH\&S rizika ispunio svoju svrhu i dao zadovoljavajuće rezultate. 
Upravljanje OH\&S rizicimau skladu sa ovim metodološkim postupkom je vrlo pouzdan i koristan alat za donosioce odluka $\mathrm{u}$ ispunjavanju politike $\mathrm{i}$ ciljeva $\mathrm{u}$ pogledu zaštite zdravlja i bezbednosti na radu.

Optimizovani model procene OH\&S rizika na bazi Kinny metode primenjen $\mathrm{u}$ ovom radu je praktično ispitan u i drugim sličnim organizacijama kao što su: Drillex International d.o.o, International Drilling Service d.o.o kao i Stara Planina Resources d.o.o. Na osnovu ovog modela je uspostavljen efikasan i efektivan sistem upravljanja zaštitom zdravlja i bezbednosti na radu u skladu sa SRPS OHSAS 18001:2008.

Iz praktične primene optimizovanog modela za procenu $\mathrm{OH} \& \mathrm{~S}$ rizika pri upravljanju OH\&S sistemom može se zaključiti da je u većini faza geološkog istražnog bušenja prisutan povećani $\mathrm{OH} \& \mathrm{~S}$ rizik ali da se istim može upravljati samo ako su primenjene planirane mere iz Plana mera za kontrolu procenjenih $\mathrm{OH} \& \mathrm{~S}$ rizika.

Ovako predloženi metodološki postupak procene $\mathrm{OH} \& \mathrm{~S}$ rizika može biti od velike koristi i u drugim organizacija koje koriste ovu metodu procene rizika ili se bave sličnom delatnošću. Procena $\mathrm{OH} \& S$ rizika i uspostavljanje kontrolnih mehanizama upravljanja je od velike koristi i pri projektovanju sistema upravljanja zaštitom zdravlja i bezbednošću na radu. Predloženi model procene $\mathrm{OH} \& \mathrm{~S}$ rizika omogućava da se informacije o $\mathrm{OH} \& \mathrm{~S}$ riziku adekvatno procesuiraju i koriste u donošenju odluka na releventnim nivoima organizacije koja se bavi izvođenjem radova na geološkim istražnim bušenjima.

Aktivnom i sve obuhvatnom procenom $\mathrm{OH} \& \mathrm{~S}$ rizika kako je to definisano ovim radom menadžment organizacije koja se bavi geološkim istražnim bušenjem može da:

- prihvata i odobrava politiku upravljanja procenjenim OH\&S rizikom;

- obaveštava sve zainteresovane strane u procesu izvođenja geoloških istražnih bušenja;
- definiše mehanizme kontrole procenjenog $\mathrm{OH} \& \mathrm{~S}$ rizika koji odgovaraju performansama organizacije;

- obezbeđuje usaglašenost sa zakonskom i podzakonskom regulativom kao i sa pravnim aktima organizacije;

- obezbeđuje raspodelu potrebnih resursa za potrebe upravljanja procenjenim $\mathrm{OH} \& \mathrm{~S}$ rizikom.

\section{LITERATURA}

[1] Anderson, K. "Intelligence-Based Threat Assessments for Information Networks and Infrastructures: A White Paper", 2005.

[2] Commoner B.: "Comparing Apples to Oranges: Risk of Cost/Benefit Analysis" from Contemporary Moral Controversies in Technology, A. P. Iannone, ed., pp. 64-65.

[3] Lerche, I. (Ian) Environmental Risk Assessment: Quantitative Measures, Anthropogenic Influences, Human Impact. Berlin: Springer, 2006.

[4] Staletović N.: Ocena OHS rizika u funkciji preventivnog inženjeringa $\mathrm{i}$ integrisanih sistema menadžmenta (QMS, EMS i OHSAS); Tehnika 59(2009)3, Menadžment, str. 8-14; Beograd.

[5] Staletović N., Tucović N.: Menadžment aspektima preventivnog inženjerstva u graditeljstvu; "IMK - 14 Istraživanje i razvoj"; Kruševac, 2009.

[6] Staletović, N., Anđelković, B., Razvoj tehnoloških sistema i preventivni inženjering, „Ekologica”, Beograd, 2(2000), str. 98-103.

[7] Standard ISO 31010:2010 Risk Management - Risk Assessment Techniques

[8] Standards Australia and Standards New Zealand; Standard Risk Management AS/NZS 4360:2009. Sydney and Wellington: Standards Australia and Standards New Zealand. 
[9] Standard SRPS OHSAS 18001: 2008 Sistem menadžmenta zaštite zdravlja i bezbednosti na radu - Zahtevi

[10] Antić R., Staletović N., Kovačević S.: Akt o proceni rizika na radnom mestu i radnoj okolini "Geops Balkan Driling Services" d.o.o; MIN Institut a.d. Niš; 2013.

[11] Staletović N., Kovačević S., Kovačević M., Tucović N.: Metodološki okvir procene rizika u funkciji održavanja rudarske opreme i upravljanja IMS
(QMS, AMS, EMS i OHSAS) u rudarskim kompanijama; Mining and Metallurgy Engineering Bor 3(2013), str. 147-159.

[12] Staletović N., Kovačević K., Kovačević M.: Metodološki pristup identifikacije aspekata i vrednovanja uticaja na životnu sredinu za projekat „Eksploatacija magnezita u ležištu Čavlovac - Masnica“, Rudarski radovi 3(2012), str. 171-182. 